\title{
Saltwater Intrusion into a River with High Fluvial Discharge: A Microtidal Estuary of the Magdalena River, Colombia
} \author{
Oscar Alvarez-Silva ${ }^{\dagger}$ \\ ${ }^{\dagger}$ Departamento de Física y Geociencias \\ Universidad del Norte \\ Barranquilla, Colombia
}

Silvio Ospino ${ }^{\dagger *}$, Juan Camilo Restrepo ${ }^{\dagger}$, Luis Otero $^{\dagger}$, Jorge Pierini ${ }^{\ddagger}$, and

${ }^{\ddagger}$ Comisión de Investigaciones Científicas de la

Provincia de Buenos Aires

Bahía Blanca, Argentina

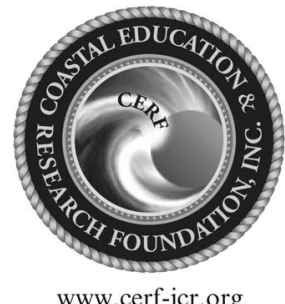

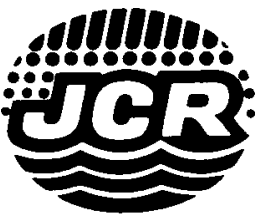

www.JCRonline.org

ABSTRACT

Ospino, S.; Restrepo, J.C.; Otero, L.; Pierini, J., and Alvarez-Silva, O., 0000. Saltwater intrusion into a river with high fluvial discharge: A microtidal estuary of the Magdalena River, Colombia. Journal of Coastal Research, 00(0), 000-000. Coconut Creek (Florida), ISSN 0749-0208.

\begin{abstract}
The Magdalena River (Bocas de Ceniza) forms a microtidal estuary subjected to numerous interventions aimed to guarantee navigability towards the port of Barranquilla, Colombia. Significant sedimentation processes are still frequent in this area, however. Understanding the dynamics of both saltwater intrusion and mixing conditions is a fundamental requisite to understanding the sedimentation dynamics in these types of estuaries. The effects of river discharge, tide, and winds on stratification patterns, and mixing and saltwater intrusion dynamics in the estuary of the Magdalena River were evaluated, focusing on the effects of river discharge variability. The three-dimensional hydrodynamic model MOHID was implemented, and calibration and validation of the model were carried out using in situ velocity, temperature, and salinity data, obtaining Skill values greater than 0.90 . To cover a wide range of variability in the main forcing factors (fluvial discharge, tide, and wind), the conditions recorded in 2010 were simulated when both phases of the El Niño-Southern Oscillation phenomenon occurred. During that year, the river discharge ranged between 2465 and $16,463 \mathrm{~m}^{3} \mathrm{~s}^{-1}$. Results revealed a stratified, saltwater wedge estuary, the dynamics of which were mainly dominated by river discharge. Tide and winds altered saltwater intrusion dynamics, mainly during low-discharge periods.
\end{abstract}

ADDITIONAL INDEX WORDS: MOHID model, estuarine dynamics, stratification, mixing conditions, ENSO influence.

\section{INTRODUCTION}

Estuaries are subjected to a complex interplay among fluvial, marine, meteorological, and geomorphological factors (Syvitski and Saito, 2007). Because all these physical factors affect mixing conditions, estuaries are usually classified according to their stratification degree as well mixed, partially mixed, or stratified (Dyer, 1997; Haralambidou, Sylaios, and Tsihrintzis, 2010; Vijith and Shetye, 2012). Typically, well-mixed estuaries have a tidal range $>4.0 \mathrm{~m}$ and are characterized by a tidal prism that favors the homogeneous mixing of the water column, and thus haloclines do not form. Partially mixed estuaries have a tidal range between 2.0 and $4.0 \mathrm{~m}$. The mixing capacity of the tide is reduced, resulting in the formation of diffuse haloclines. Stratified estuaries are usually microtidal environments (tidal range $<2.0 \mathrm{~m}$ ), with a well-defined halocline that separates the almost homogeneous freshwater and saltwater bodies. The depth of the halocline defines the general form of what is known as a salt wedge-the layer of saltwater that penetrates the mouth of a river and migrates upstream, underneath the freshwater (Rattray and Mitsuda, 1974). The dynamics of such systems, particularly those with relatively low levels of human intervention (e.g., Strymon, Yura, or Ebro River estuaries), have been widely studied. Generally, there is a strong seaward fluvial flux in the upper layer and a weak landward marine flux in the bottom layer.

DOI: 10.2112/JCOASTRES-D-17-00144.1 received 17 August 2017; accepted in revision 10 April 2018; corrected proofs received 29 May 2018; published pre-print online 25 June 2018.

*Corresponding author: osilvio@uninorte.edu.co

${ }^{\circledR}$ Coastal Education and Research Foundation, Inc. 2018
Salt wedges generally propagate upstream as horizontal gravity currents and depend on the balance between tidal forces and the resistance imposed by the seaward flow of freshwater (Simpson, 1987). Consequently, a salinity gradient causes the formation of a very stable halocline and thus prevents vertical mixing. In these stratified estuary systems, mixing mainly develops because of the shear stress beneath, and within the halocline (Dyer, 1997). The position of a salt wedge is thus determined by the equilibrium between the baroclinic pressure gradient (caused by the difference in longitudinal density) and the advection induced by the flow of the river (D'Adamo and Lukatelich, 1985). This equilibrium allows the salt wedge to reach a quasi-stationary state known as an arrested salt wedge (Rattray and Mitsuda, 1974). As this regime plays an important role in sedimentation processes of estuaries (Hinwood, 1994; Restrepo et al., 2016) and in the spatial distribution of nutrients, chemical compounds, and pollutants (Delandmeter et al., 2015), different parameterizations have been formulated to predict the position of the salt wedge (e.g., Hinwood, 1994; Officer, 1976).

Salt-wedge intrusion in the Magdalena River estuary has been poorly studied. Its role in siltation processes has been highlighted recently, linking the formation and magnitude of the estuarine turbidity maximum (ETM) with both the saline convergence front dynamics and turbulence weakening (Restrepo et al., 2018). Furthermore, in this particular case, saltwedge intrusion might lead to serious socioeconomic conflicts due to the tensions related to fluvial-water supply for domestic, agricultural, and industrial uses. Given the influence that saltwater intrusion has on water quality and sedimentation 
processes, human interventions have been performed at some river mouths to control this phenomenon (Haralambidou, Tsihrintzis, and Sylaios, 2003) and reduce sedimentation rates (Van Rijn, 2005). In the case of the mouth of the Magdalena River (Figure 1), the system has been subjected to significant human intervention for almost a century. However, despite the various jetties, breakwaters, and training walls that have been built to regulate the flow and reduce sedimentation rates, the Magdalena River still experiences frequent navigability problems related to sedimentation processes. Therefore, the river channel must undergo periodic dredging to keep it navigably active (Restrepo et al., 2016). Although several initiatives have been launched to characterize the sedimentation processes at this river mouth (e.g., Alvarado, 1992; NEDECO, 1973), very few studies have highlighted the relationships among its stratification, mixing conditions, and sedimentation. Restrepo et al. (2016) demonstrated that the variations in the river flow and the associated stratification patterns play a central role in the sedimentary dynamics of the estuary. The conjugated effects of salt wedge and tide lead to a stable ETM in the saline convergence front, with near-bed upstream currents favoring sediment trapping (Burchard and Baumert, 1998). The ETM favors a weakening of turbulence and consequently of the mixing conditions. Here, stratification might be also strengthened by the high sediment concentration, and presumably by flocculation (e.g., Manning et al., 2010). In this study, the dynamics of the saltwater intrusion in the estuary of the Magdalena River was investigated in order to: (1) understand the forcing behind the spatial distribution of salinity in the navigable channel; (2) identify the dominant forcing factors in the dynamics of the saltwater intrusion; and (3) analyze the effect that this forcing exerts on the stratification and mixing conditions of the estuary. The aim focused heavily on the effects of river discharge variability. The study of each of these aspects is a fundamental prerequisite to fully understand the sedimentary dynamics of the Magdalena River.

\section{Study Area: The Mouth of the Magdalena River}

The mouth of the Magdalena River forms a $1690 \mathrm{~km}^{2}$ arcuate delta characterized by alluvial plains, sandpits, and marginal lagoon complexes. Deposition of sediments along the delta front has resulted in the formation of a shelf and a large-scale subtidal channel spanning the NNE sector. Moreover, in the prodelta, a steep $\left(\sim 40^{\circ}\right)$ underwater canyon is aligned with the mouth of the river. The morphology and sedimentary architecture of this canyon are closely related to the high sedimentary contribution of the river (Ercilla et al., 2002), estimated at $142.6 \times 10^{6} \mathrm{t} \mathrm{yr}^{-1}$ of suspended sediments (Restrepo et al., 2016). Human interventions aimed to mitigate sedimentation processes and promote commercial navigation towards the port of Barranquilla have resulted in significant morphological changes to the main mouth of the Magdalena River (Bocas de Ceniza). Since 1936, the construction of two jetties at the mouth of the river has forced the discharge path to follow a quasi-rectilinear orientation. These eastern and western jetties have lengths of 1.4 and $7.4 \mathrm{~km}$, respectively (Figure 1). The main objective of these works was to reduce the width of the mouth, increase the flow rate, and thereby increase the capacity to transport sediment. Even following the implementation of these projects, sedimentation processes continued to be a major problem. In 1942 and 1945, for instance, a frontal bar formed at the mouth of the river. In response to these events, the jetties were reinforced and extended by an additional $120 \mathrm{~m}$ in 1949 and an additional $53 \mathrm{~m}$ in 1951. Between 2008 and 2009, two contraction groynes, 0.67 and $0.23 \mathrm{~km}$ long, were built on the northern segment of the eastern jetty to further reduce the width of the mouth. Currently, the river mouth is $430 \mathrm{~m}$ wide, with a minimum depth of $9.15 \mathrm{~m}$ in the navigable channel (Restrepo et al., 2016).

The mouth of the Magdalena River is characterized by a predominantly diurnal, mixed microtidal regime. The most significant harmonic constituents at the mouth are $\mathrm{K}_{1}$ (lunisolar diurnal), $\mathrm{M}_{2}$ (principal lunar), and $\mathrm{O}_{1}$ (principal lunar diurnal) (Figure 2D). The tidal range oscillates between $0.13 \mathrm{~m}$ during neap tide and $0.40 \mathrm{~m}$ during spring tide. It has been reported that the tide reaches a maximum amplitude of $0.20 \mathrm{~m}$ approximately $22 \mathrm{~km}$ upstream of the river mouth (Alvarado, 1992). Surface salinity in the Caribbean Basin of Colombia ranges from approximately 33 to 37 . While the general circulation of the Caribbean Sea dominates the variability in salinity within the deeper layers of this basin, the more superficial layers are controlled by changes in river discharge, wind circulation patterns, and upwelling. The upper layers exhibit considerable seasonal variability in salinity (Ruiz-Ochoa et al., 2010).

Studies looking at the intrusion of saltwater into the Magdalena estuary are scarce. Restrepo et al. (2016) showed, however, that there is a pronounced difference in the salinity structure during the high- and low-river-discharge seasons. A well-defined shallow halocline forms in the deltaic front during the high-discharge season, while a deep halocline forms at the river mouth. In contrast, during the low-discharge season, the salt wedge penetrates approximately $4 \mathrm{~km}$ upstream of the river mouth, with salinity values lower than 20 in the deep layers. Moreover, the final stretch of the channel of the Magdalena River is characterized by a column of stratified water during the low-discharge season, while such stratification is not observed in this section during the high-discharge season.

The wind patterns in the Caribbean are defined by the latitudinal migration of the Intertropical Convergence Zone (ITCZ). During August, the ITCZ is located in the Northern Hemisphere at approximately $10^{\circ} \mathrm{N}$ (over the Caribbean Sea). At this time, the trade winds that cross the equatorial zone from the Southern Hemisphere acquire a westerly component and are characterized by low magnitudes and variable directions. On the other hand, in January, the ITCZ is located further south $\left(2^{\circ} \mathrm{N}\right)$, and this results in the generation of strong and constant northeast trade winds (Andrade, 1993). The mouth of the Magdalena River experiences the strongest winds between the months of December and April, with average values ranging from 7.3 to $9.2 \mathrm{~m} \mathrm{~s}^{-1}$. The rest of year, winds are typically weaker, with values falling below the long term average of $6.5 \mathrm{~m} \mathrm{~s}^{-1}$ (Figure 2A). These winds mainly come from the NE (43\%) and the NNE (30\%) (Figure 2B). The annual wind cycle changes during El Niño-Southern Oscillation (ENSO) events: During El Niño, there is a reduction in wind velocities in the December-January-February and March-April-May 

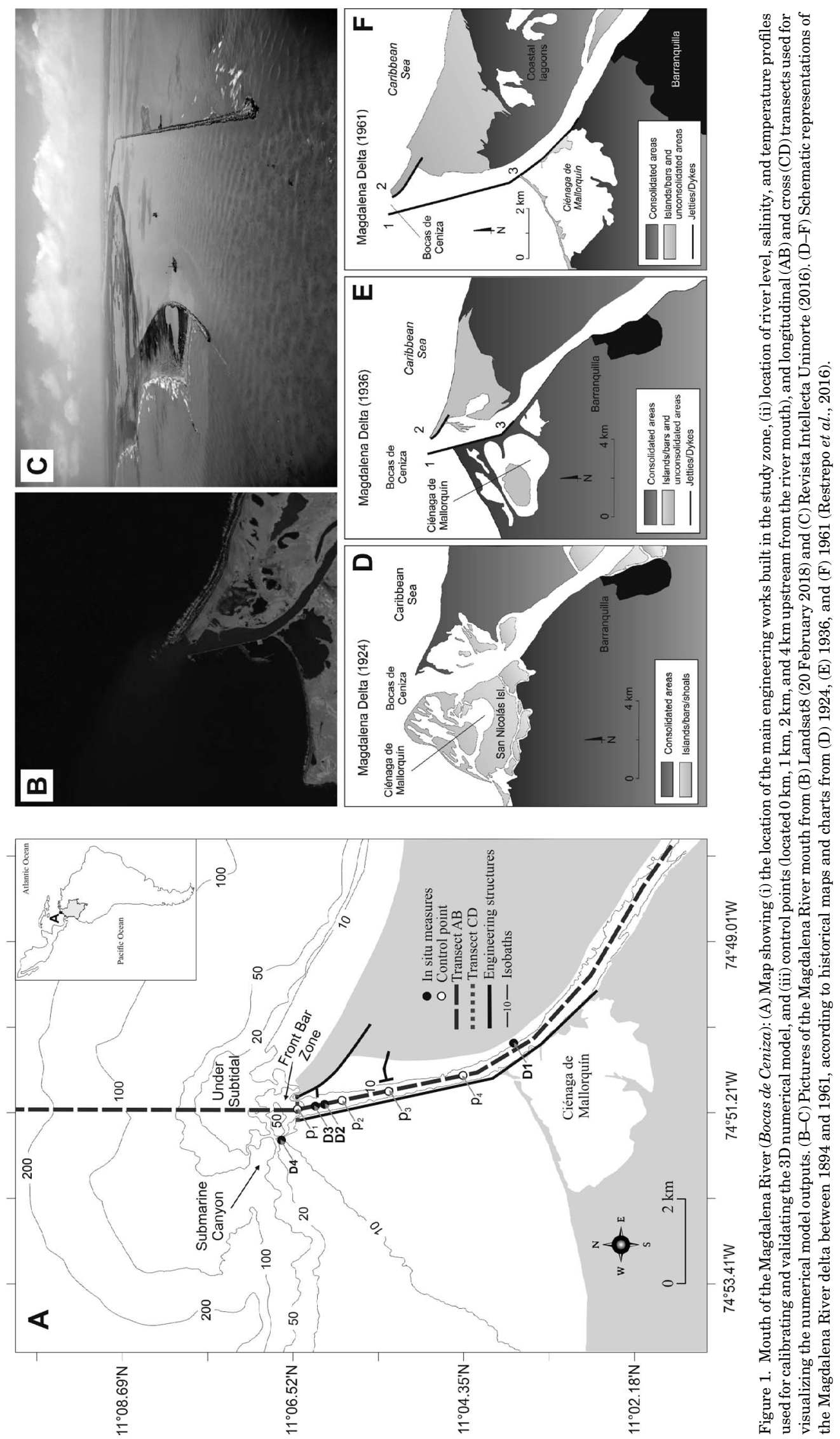

영 :

政

a

.:

30

की

空:

$\sum_{0}$

4 的

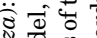

₹

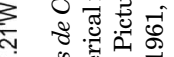

造

\&

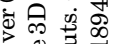

政

ส

要:

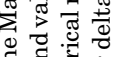

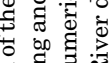

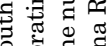

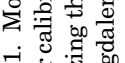

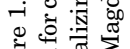

Un 

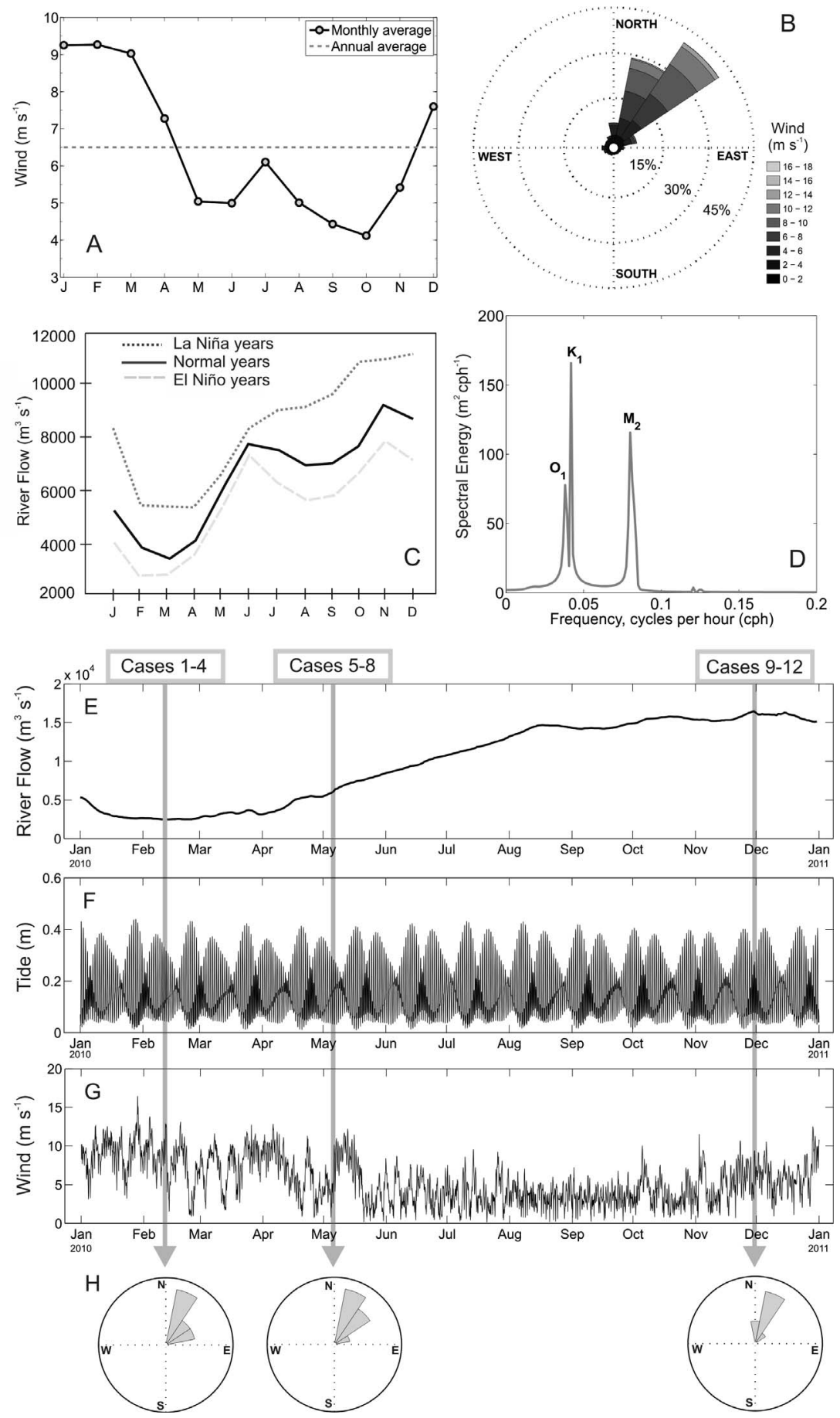

Figure 2. Characteristics of the main environmental drivers at the Magdalena River mouth. (A) Monthly and annual averaged wind velocities and (B) the wind rose (both obtained from Global Forecast System [GFS] data). (C) Monthly averaged discharge during non-ENSO years, El Niño and La Niña (Restrepo et al., 2014). (D) Spectral energy of main tidal harmonics measured $\sim 6 \mathrm{~km}$ inside the river mouth. Variability of the main drivers during 2010: (E) daily streamflow at Calamar gauging station (IDEAM), (F) hourly astronomic tide obtained from Fes2004, (G) wind velocity extracted from GFS data (3 hour time resolution), and (H) daily wind rose for the dates shown in Table 2 . 
quarters but an increase in velocities in the June-July-August and September-October-November quarters. In contrast, the opposite pattern occurs during La Niña phenomena (Bernal, Ruiz-Ochoa, and Beier, 2010).

The Magdalena River experiences low streamflow $\left(<4500 \mathrm{~m}^{3}\right.$ $\mathrm{s}^{-1}$ ) between February and April and high streamflow $(>7500$ $\mathrm{m}^{3} \mathrm{~s}^{-1}$ ) between October and December. The average annual flow of the river is estimated to be $6334.9 \mathrm{~m}^{3} \mathrm{~s}^{-1}$, with a monthly maximum and minimum flow of 16,913 and $1520 \mathrm{~m}^{3} \mathrm{~s}^{-1}$, respectively (Higgins et al., 2016; Restrepo et al., 2014). The years affected by ENSO events might experience significantly different values at the extremes of the annual cycle, with an increase of up to $61 \%$ and a decrease of up to $23 \%$ during La Niña and El Niño, respectively (Figure 2C). Although some studies have shown an important correlation between ENSO and the flow of the Magdalena River, with ENSO accounting for up to $65 \%$ of the interannual variability (e.g., Restrepo and Kjerfve, 2000), Restrepo et al. (2014) indicated a less significant role of ENSO in streamflow variability, since the annual and quasi-decadal (i.e. 8-12 years) bands are the main oscillatory components of hydrological variability, whereas the interannual band (i.e. ENSO) represents a second-order source of variability.

\section{METHODS}

A baroclinic three-dimensional (3D) numerical model (MOHID 3D, where MOHID stands for Modelo Hidrodinâmico) was employed to simulate salt intrusion, mixing, and stratification in the Magdalena River mouth. This model is capable for simulating estuarine and coastal fluxes under different scenarios (e.g., Coelho et al., 1999; Martins et al., 2001; Restrepo et al., 2017; Vaz, Dias, and Leitão, 2009). This model solves the $3 \mathrm{D}$ equations for incompressible fluids, assuming a hydrostatic equilibrium and employing the Boussinesq and Reynolds approaches (Martins et al., 2001):

$$
\begin{gathered}
\frac{\partial u_{i}}{\partial x_{i}}=0 \\
\frac{\partial u_{i}}{\partial t}+\frac{\partial\left(u_{i} u_{j}\right)}{\partial x_{j}}=-\frac{1}{\rho_{0}} \frac{\partial p_{a t m}}{\partial x_{i}}-g \frac{\rho(\eta)}{\rho_{0}} \frac{\partial \eta}{\partial x_{i}}-\frac{g}{\rho_{0}} \int_{x_{3}}^{\eta} \frac{\partial \rho^{\prime}}{\partial x_{i}} d x_{3} \\
+\frac{\partial}{\partial x_{i}}\left(v \frac{\partial u_{i}}{\partial x_{j}}\right)-2 \varepsilon_{i j k} \Omega_{j} u_{k},
\end{gathered}
$$

where, $u_{i}$ represents the velocity components along the Cartesian directions $x_{i}$, while $\eta, v, g$, and $p_{\text {atm }}$ represent the free surface elevation, turbulent viscosity, gravity, and atmospheric pressure, respectively, and $\rho$ and $\rho^{\prime}$ are the water density and its anomaly $\left(\rho=\rho^{\prime}+\rho_{0}\right)$. The Coriolis force is represented through the last term in Eq. (2). The UNESCO state equation (UNESCO, 1981) was used for estimating water density. Salinity and temperature were transported using the momentum equations (Martins et al., 2001). The transport equations were discretized numerically using the finite volume method, through the Arakawa-C stepped grid (Arakawa, 1966). The equations were solved through a semi-implicit algorithm (Alternative Direction Implicit [ADI]) that calculates the change of water elevation and the evolution of the velocity based on Abbott, Damsgaard, and Rodenhuis (1973) and Leendertse (1967). The vertical coordinate of MOHID is generic, allowing the employment of various types of coordinates (i.e. sigma, Cartesian, isopic, or Lagrangian) (Martins, Neves, and Leitão, 1998). Horizontal and vertical transport of temperature and salinity were calculated explicitly and implicitly, respectively (Mateus et al., 2012). Horizontal turbulent diffusion was approached through the Smagorinsky method (Smagorinsky, 1963). Baroclinic force was calculated using a level $z$ technique for any vertical coordinate, whereby a horizontal density gradient was estimated (Mateus et al., 2012). The shear bottom stress was also calculated implicitly as a part of the boundary condition linked to the vertical diffusion term (Mateus et al., 2012). Finally, MOHID was coupled with the General Ocean Turbulence Model (GOTM) model to calculate vertical viscosity by modelling the turbulent kinetic energy equations and turbulent dissipation rate through application of the type $k-\varepsilon$ model (Rodi, 1987). This approach has been broadly used (Canuto et al., 2001; Luyten et al., 1996).

\section{Data for Model Implementation}

Bathymetric data provided by the National Hydrographic Service were processed to design a structured calculation mesh of $120 \times 162$ cells with constant $100 \mathrm{~m}$ spacing in the horizontal direction and a vertical sigma discretization of 10 layers. The baroclinic approach was employed for simulating saltwater intrusion, considering river discharge, astronomical tide, and wind as driving mechanisms. Daily discharge data from the Calamar station $\left(10.255102^{\circ} \mathrm{N}, 74.907584^{\circ} \mathrm{W}\right)$, the closest to the river mouth, were used; the astronomical tide harmonics were taken from the Fes2004 global tide model (Table 1); and zonal and meridional wind velocities with time resolution of 3 hours were obtained from the Global Forecast System, at a point located in front of the mouth of the Magdalena River $\left(11.1666^{\circ} \mathrm{N}, 74.8333^{\circ} \mathrm{W}\right)$. Initial conditions were set as 36.0 for salinity and $27.4^{\circ} \mathrm{C}$ for temperature for the entire domain, according to previous measurements performed in the Colombian Caribbean Basin (e.g., Bernal, Ruiz-Ochoa, and Beier, 2010; Ruiz-Ochoa et al., 2010) and within the values measured by Restrepo et al. (2016) at both the mouth and delta front. In contrast, the river discharge was characterized by a salinity and temperature of $\sim 0.07$ and $\sim 30.7^{\circ} \mathrm{C}$, respectively.

\section{Calibration and Validation of the Numerical Model}

The numerical model was calibrated and validated using in situ data. Initially, sensitivity tests were conducted to evaluate the optimal conditions of vertical discretization, bed roughness, and eddy viscosity (procedures not shown for brevity). The best fit was obtained for a sigma vertical discretization of 10 layers and bottom roughness of $0.0025 \mathrm{~m}$. The horizontal turbulence model Smagorinsky and the vertical turbulence model kepsilon were used for the calibration and validation of the numerical model.

Assuming a relaxation time of 10 days, the hydrodynamic calibration of the model was performed using water-surface elevation data measured at $\sim 6 \mathrm{~km}$ upstream of the river mouth and salinity/temperature profiles measured along the navigable channel. Elevation data were taken over 14 days (18-31 March 2014) using a RBR DR-1060 ${ }^{\oplus}$ sensor, while salinity and temperature profiles were measured with a CTD SeaBird 
Table 1. Harmonic components of the tide in the study zone, taken from FES2004 model.

\begin{tabular}{lccc}
\hline \hline Harmonic & Period $(\mathrm{h})$ & Amplitude $(\mathrm{m})$ & Phase $\left(^{\circ}\right)$ \\
\hline$M_{2}$ & 12.42 & 0.06740610 & 126.2100 \\
$S_{2}$ & 12.00 & 0.00806993 & 32.5322 \\
$K_{1}$ & 23.93 & 0.09293130 & -119.4320 \\
$K_{2}$ & 11.97 & 0.01085130 & 14.2867 \\
$N_{2}$ & 12.66 & 0.02625460 & 108.4130 \\
$2 N_{2}$ & 12.91 & 0.00368386 & 70.6246 \\
$O_{1}$ & 25.82 & 0.05379000 & -125.9750 \\
$Q_{1}$ & 26.87 & 0.03060430 & -120.0860 \\
$P_{1}$ & 24.07 & 0.00893939 & -137.8770 \\
$M f$ & 327.86 & 0.01681680 & -4.1648 \\
$M m$ & 661.30 & 0.00809742 & -6.4744 \\
$M t m$ & 219.19 & 0.00340095 & 0.145009 \\
$M S q m$ & 170.30 & 0.00047171 & -1.12319 \\
\hline
\end{tabular}

19Plus ${ }^{\circledast}$ during the dry period (20 April 2013). Finally, to validate the model, salinity and temperature profiles measured in both the rainy (November 29, 2012) and dry (April 21, 2013) seasons were compared with simulation results from the same dates. The prediction error of the model was quantified in terms of the Skill (3) and RMSE (4) indicators:

$$
\begin{gathered}
\text { Skill }=1-\frac{\sum_{i=1}^{N}\left(M_{i}-S_{i}\right)^{2}}{\sum_{i=1}^{N}\left[\left(S_{i}-\bar{M}\right)+\left(M_{i}-\bar{M}\right)\right]^{2}} \\
R M S E=\sqrt{\frac{\sum_{i=1}^{N}\left(M_{i}-S_{i}\right)^{2}}{N}}
\end{gathered}
$$

where, $M_{i}$ and $S_{i}$ represent the measured and simulated data, respectively; $\bar{M}$ is the average of the measured data; and $N$ is the number of data points. A perfect fit is indicated by $S k i l l=1$ and $\mathrm{RMSE}=0$.

\section{Simulated Scenarios}

The in situ measurements along with the results found by Restrepo et al. (2016) in the Magdalena River emphasize the importance of river discharge in the processes of stratification, mixing, and saltwater intrusion. Various river discharge scenarios were evaluated, including the annual average and extreme conditions. Variations in discharge during 2010 (Figure 2E) were considered, because this year was characterized by both phases of the ENSO, in conjunction with other climatic events (Restrepo et al., 2014). El Niño of 2010 brought a minimum discharge of $2465 \mathrm{~m}^{3} \mathrm{~s}^{-1}$, while during La Niña, there was a maximum discharge of $16,463 \mathrm{~m}^{3} \mathrm{~s}^{-1}$. The mean/ minimum/maximum discharge scenarios were combined with high/low-tide conditions and wind/calm situations for a total of 12 modelled scenarios (Table 2). An average NNE wind of $8.0 \mathrm{~m}$ $\mathrm{s}^{-1}$ was used in those scenarios (Figure $2 \mathrm{G}, \mathrm{H}$ ). The stratification and mixing were quantified for all scenarios using the stratification parameter $\left(n_{\mathrm{s}}\right)$ and the Richardson layered number $\left(R_{\mathrm{L}}\right)$, where the stratification parameter $\left(n_{\mathrm{s}}\right)$ was determined by:

$$
n_{s}=\delta S / S_{m}
$$

where, $\delta S$ is the difference in salinity between the bottom and the surface, and $S_{\mathrm{m}}$ corresponds to the average salinity in the water column. When the water column is well mixed, $n_{\mathrm{s}}<0.1$; when it is partially mixed, $0.1<n_{\mathrm{s}}<1.0$; and when $n_{\mathrm{s}}>1.0$, the water column is stratified, and the presence of a salt wedge is evident (Haralambidou, Sylaios, and Tsihrintzis, 2010). The weakening of the turbulent mixing leads to permanent or prolonged stratification (Prandle, 2009). The main distinction between mixing conditions was determined according to the Richardson layered number $\left(R_{\mathrm{L}}\right)$ :

$$
R_{L}=\frac{g h\left(\rho_{b}-\rho_{s}\right)}{\bar{u}^{2} \rho_{o}}
$$

where, $g$ is the gravitational acceleration $\left(\mathrm{m} \mathrm{s}^{-2}\right), h$ is the depth of the water layer $(\mathrm{m}), \bar{u}$ is the depth-averaged velocity $\left(\mathrm{m} \mathrm{s}^{-1}\right)$, $\rho_{\mathrm{o}}$ is the depth-averaged density $\left(\mathrm{kg} \mathrm{m}^{-3}\right)$, and $\left(\rho_{\mathrm{b}}-\rho_{\mathrm{s}}\right)$ is the difference in density between the bottom layer and the surface layer $\left(\mathrm{kg} \mathrm{m}^{-3}\right.$ ) (Dyer, 1997; Kitheka, Obiero, and Nthenge, 2005). $R_{\mathrm{L}}$ enables a quantitative estimation of the mixing intensity and is dependent on the variations in flow and tide. For $R_{\mathrm{L}}$ values $>20$, the water column is considered to be stable, and bottom turbulence is not effective enough to generate mixing. Meanwhile, when $2<R_{\mathrm{L}}<20$, the turbulence mixing becomes more effective. If $R_{\mathrm{L}}<2$, the turbulence generated by bottom friction is the fundamental mechanism of mixing (Dyer, 1997).

After evaluating the average-discharge condition, the surface area of dissolution was defined by considering the domain

\begin{tabular}{|c|c|c|c|c|c|c|}
\hline \multirow{2}{*}{$\begin{array}{c}\text { Date } \\
\text { DD/MM/AAAA }\end{array}$} & \multirow{2}{*}{$\begin{array}{l}\text { Streamflow } \\
\left(\mathrm{m}^{3} \mathrm{~s}^{-1}\right)\end{array}$} & \multirow{2}{*}{$\begin{array}{l}\text { Tidal State } \\
\text { (ebb/flood) }\end{array}$} & \multicolumn{2}{|c|}{ Wind } & \multirow[b]{2}{*}{ Case } & \multirow[b]{2}{*}{ Code } \\
\hline & & & Magnitude $\left(\mathrm{m} \mathrm{s}^{-1}\right)$ & Direction & & \\
\hline $12 / 02 / 2010$ & 2465 & Ebb & - & - & 1 & C1 \\
\hline $12 / 02 / 2010$ & 2465 & Ebb & 8.0 & NNE & 2 & $\mathrm{C} 2$ \\
\hline $12 / 02 / 2010$ & 2465 & Flood & - & - & 3 & C3 \\
\hline $12 / 02 / 2010$ & 2465 & Flood & 8.0 & NNE & 4 & $\mathrm{C} 4$ \\
\hline 06/05/2010 & 6052 & Ebb & - & - & 5 & C5 \\
\hline 06/05/2010 & 6052 & Ebb & 8.0 & NNE & 6 & $\mathrm{C} 6$ \\
\hline 06/05/2010 & 6052 & Flood & - & - & 7 & $\mathrm{C} 7$ \\
\hline 06/05/2010 & 6052 & Flood & 8.0 & NNE & 8 & $\mathrm{C} 8$ \\
\hline $30 / 11 / 2010$ & 16,463 & Ebb & - & - & 9 & C9 \\
\hline $30 / 11 / 2010$ & 16,463 & Ebb & 8.0 & $\mathrm{NNE}$ & 10 & $\mathrm{C} 10$ \\
\hline $30 / 11 / 2010$ & 16,463 & Flood & - & - & 11 & C11 \\
\hline $30 / 11 / 2010$ & 16,463 & Flood & 8.0 & NNE & 12 & $\mathrm{C} 12$ \\
\hline
\end{tabular}
of water with salinities ranging between 0.5 and 30 (Kinne,

Table 2. Simulation scenarios. For mean-discharge conditions, a date when the discharge was similar to the long-term average was selected. For extreme conditions, the minimum and maximum discharge of 2010 where chosen. 

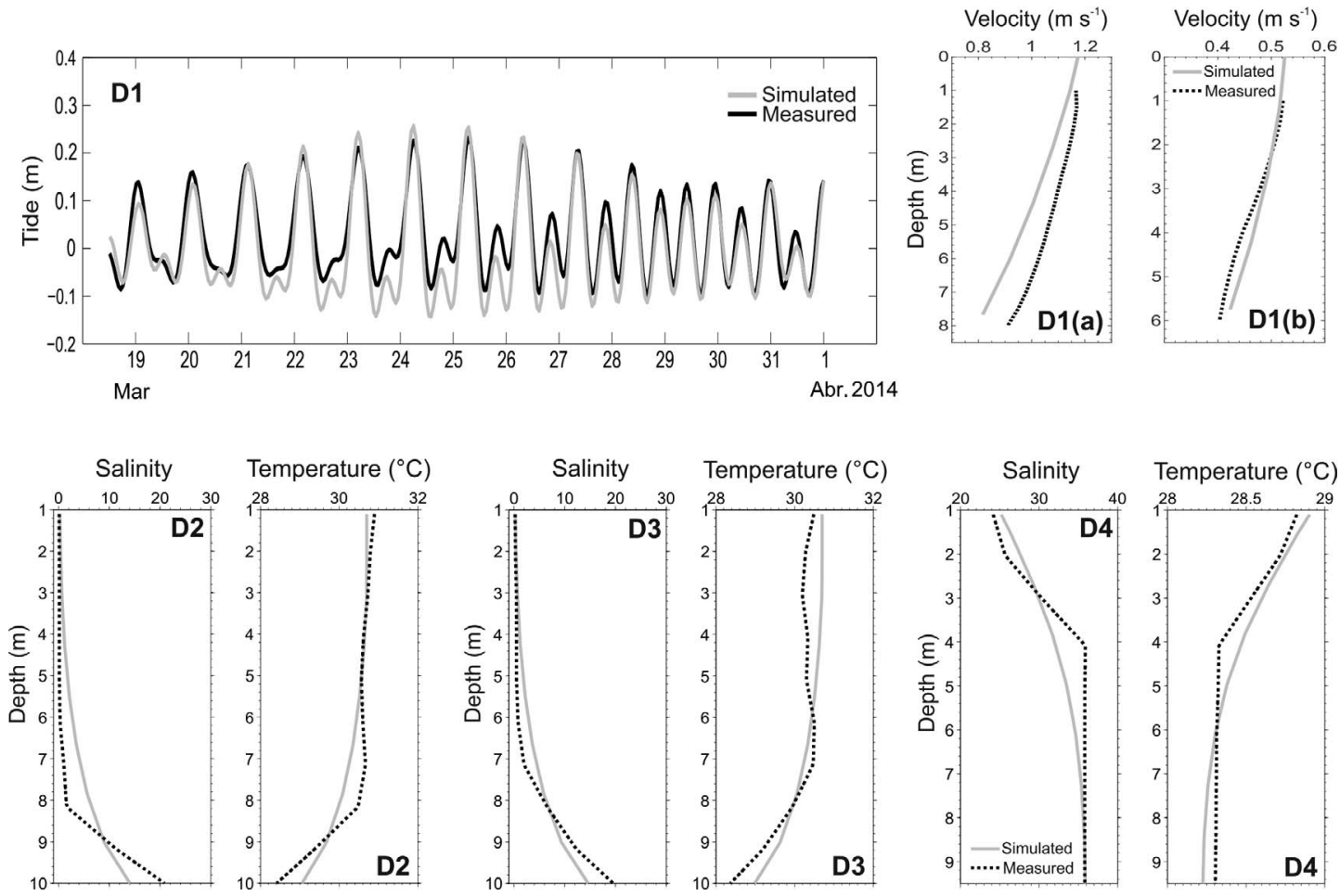

Figure 3. Comparison between in situ data and numerical model results for (D1) water level and velocity in (a) wet season and (b) dry season, (D2) salinity and temperature calibration during the dry season, (D3) salinity and temperature validation during the dry season, and (D4) salinity and temperature validation during the wet season.

1971). The average depth of this water domain was then calculated in order to estimate the average volume of the estuary. In this way, the stratification diagram proposed by Vijith and Shetye (2012) may be applied using the discharge and tidal range shown in Figure 2. This diagram assumes that stratification depends primarily on the relationships $t_{\mathrm{r}} / h$ and $R \tau / V_{\mathrm{e}}$, where, $t_{\mathrm{r}}$ is the tidal range $(\mathrm{m}), R$ is the streamflow $\left(\mathrm{m}^{3}\right.$ $\left.\mathrm{s}^{-1}\right), h$ is the average depth $(\mathrm{m}), \tau$ is the timescale ( 1 day), and $V_{\mathrm{e}}$ is the volume of the estuary $\left(\mathrm{m}^{3}\right)$. This diagram has successfully replicated stratification state (i.e. mixed, partially mixed, stratified) in numerous estuaries with a well-defined main channel (e.g., Godavari estuary, Mandovi estuary, and Guadiana estuary). In addition to evaluating both the average and extreme 2010 discharge conditions, other streamflows were also evaluated (i.e. $3600,4800,8400$, and $12,000 \mathrm{~m}^{3} \mathrm{~s}^{-1}$ ) in order to obtain a mathematical function capable of estimating the maximum penetration of different isohalines (i.e. 1, 10, 20, and 30) into the navigable channel for a given streamflow condition. For these scenarios, high-tide conditions were considered, but due to its more random nature, the effect of wind was omitted.

\section{RESULTS}

The comparison between the simulated and measured data (water level and flow velocity) $\sim 6 \mathrm{~km}$ upstream of the river mouth (Figure 3, D1), yielded a Skill value of 0.95 and a RMSE of 0.04 for water level; and a Skill value of $0.80-0.95$ and a
RMSE value of $0.01-0.08$ for flow velocity. The calibration results with respect to the vertical distribution of salinity and temperature for the dry period, along with the validation of the model for both wet and dry periods, are shown in Figure 3, D2D4, respectively. The estimated Skill prediction values are higher than 0.90 for all cases (Table 3), similar to those reported in studies applying similar approaches (e.g., Días and Lopes, 2006; Díaz et al., 2009; Martins et al., 2007; Oliveira, Fortunato, and Pinto, 2006).

\section{Saltwater Intrusion in the Magdalena River}

The calibrated and validated $3 \mathrm{D}$ model was used to simulate saltwater intrusion into the Magdalena River under different scenarios (Table 2). The results of the vertical distribution of salinity (Figures 4-5) along the longitudinal $\mathrm{AB}$ transect (Figure 1) show the salt wedge penetration upstream under

Table 3. Skill and RMSE values from comparing measurements and simulation results during calibration and validation of the model.

\begin{tabular}{llcc}
\hline \hline Season & Estimator & Salinity & Temperature \\
\hline Calibration & & & \\
Dry & RMSE & 2.51 & 0.25 \\
Dry & Skill & 0.92 & 0.94 \\
Validation & & & \\
Dry & RMSE & 1.69 & 0.31 \\
Dry & Skill & 0.96 & 0.90 \\
Wet & RMSE & 1.60 & 0.07 \\
Wet & Skill & 0.95 & 0.96 \\
\hline
\end{tabular}



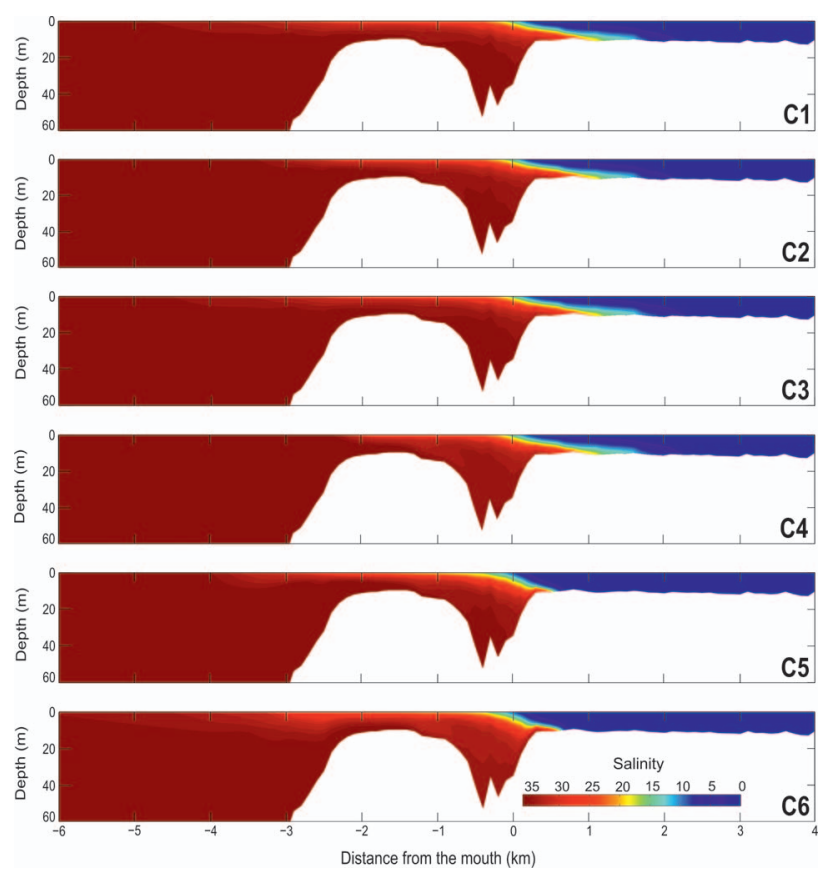

Figure 4. Vertical distribution of salinity along the longitudinal transect $A B$ (Figure 1) during low (C1 to C4) and mean (C5 and C6) streamflow conditions.

minimal- and medium-discharge conditions (Figures 4 and 5, C7-C8). In contrast, under maximum-discharge conditions (Figures 5, C9-C12), the saltwater convergence front remained confined to the river mouth (i.e. it only reached as far as $300 \mathrm{~m}$ upstream). More specifically, it stayed close to the depression located before the subtidal shoal of the delta. The maximum upstream penetration of the salt wedge occurred under conditions of minimal discharge $\left(2465 \mathrm{~m}^{3} \mathrm{~s}^{-1}\right)$ and high tide $(0.2 \mathrm{~m})$. In these conditions, the $30,20,10$, and 1 isohalines intersected the channel bed at $0.6,1.1,1.8$, and $2.7 \mathrm{~km}$, respectively. In spring-tide, the salt front was located at 2.2 and $2.9 \mathrm{~km}$ upstream of the river mouth during low and high tide, respectively; the salt-wedge location shifted up to $0.7 \mathrm{~km} \mathrm{In}$ neap tide, this shift was less than $0.2 \mathrm{~km}$, and the salt front was located at 2.3 and $2.5 \mathrm{~km}$ upstream of the river mouth during low- and high-tide, respectively.

Furthermore, in absence of tide forcing, the salt wedge penetrated up to $2.4 \mathrm{~km}$ upstream of the river mouth. The force of the wind did not significantly affect the maximum penetration of the salt wedge (Figures 4-6). During minimum-, medium-, and maximum-discharge conditions, the maximum difference in salinity between the bottom and surface layers ( $\sim 30$ salinity) was located $0.3,0.2$, and $0.0 \mathrm{~km}$ upstream from the river mouth, respectively. Consequently, the most pronounced haloclines were formed in these zones.

During high-discharge conditions, deep haloclines were present in the navigable channel. Also, at the mouth of the river (transversal CD transect; Figure 1), the depth of the haloclines increased according to river discharge (Figure 7). Moreover, the isohalines exhibited a cross-channel tilt, where
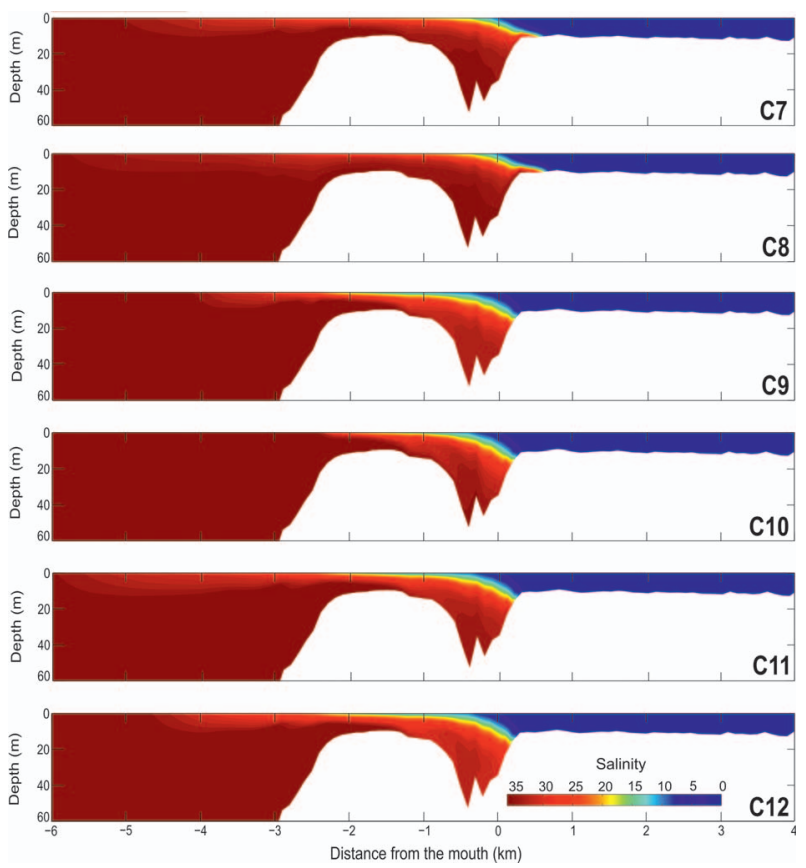

Figure 5. Vertical distribution of salinity along the longitudinal transect $A B$ (Figure 1) during mean (C7 and $\mathrm{C} 8$ ) and high (C9 to $\mathrm{C} 12)$ streamflow conditions.

the depth of the halocline increased from the eastern to western margin of the river. For example, during high-discharge conditions, an isohaline of 10 showed a depth of $\sim 5 \mathrm{~m}$ on the eastern margin but a depth of $\sim 10 \mathrm{~m}$ on the western margin (Figure 7, C9-C12).

These results demonstrate that the dynamics of the salt wedge in the Magdalena River are mainly controlled by the river's discharge (Figures 4-6 and 8). The positions at which the isohalines intercept the channel bed can be described by a power function: $X=a Q^{-b}$ (Figure 8). In this function, $X$ represents the maximum penetration of a given isohaline $(\mathrm{km})$, $Q$ represents the discharge $\left(\mathrm{m}^{3} \mathrm{~s}^{-1}\right)$, and $a$ and $b$ represent the fit coefficients. This means that the penetration of the salt wedge decreases as the river discharge increases. For example, the $1,10,20$, and 30 isohalines under minimal-discharge conditions $\left(Q=2465 \mathrm{~m}^{3} \mathrm{~s}^{-1}\right)$ penetrated $2.7,1.8,1.1$, and $0.6 \mathrm{~km}$ upstream of the river mouth, respectively. Under maximumdischarge conditions $\left(Q=16,463 \mathrm{~m}^{3} \mathrm{~s}^{-1}\right)$, the isohalines only reached approximately $0.4,0.3,0.2$, and $0.1 \mathrm{~km}$ inland. This power function provided the best fit to the simulated data (other fits not shown for brevity), having coefficients of determination higher than $R^{2}>0.92$ with statistical significance levels above 95\% ( $p \leq 0.05$ ). The equations for the prediction of the intrusion of each isohaline are shown in Table 4.

Under maximum-discharge conditions, surface salinity at the delta front was notably reduced, leading to a large area of dissolution. The surface layer of the delta front exhibited salinities of 10,20 , and 30 up to $1.0,2.4$, and $3.8 \mathrm{~km}$ offshore from the river mouth, respectively. The wind dynamics also 

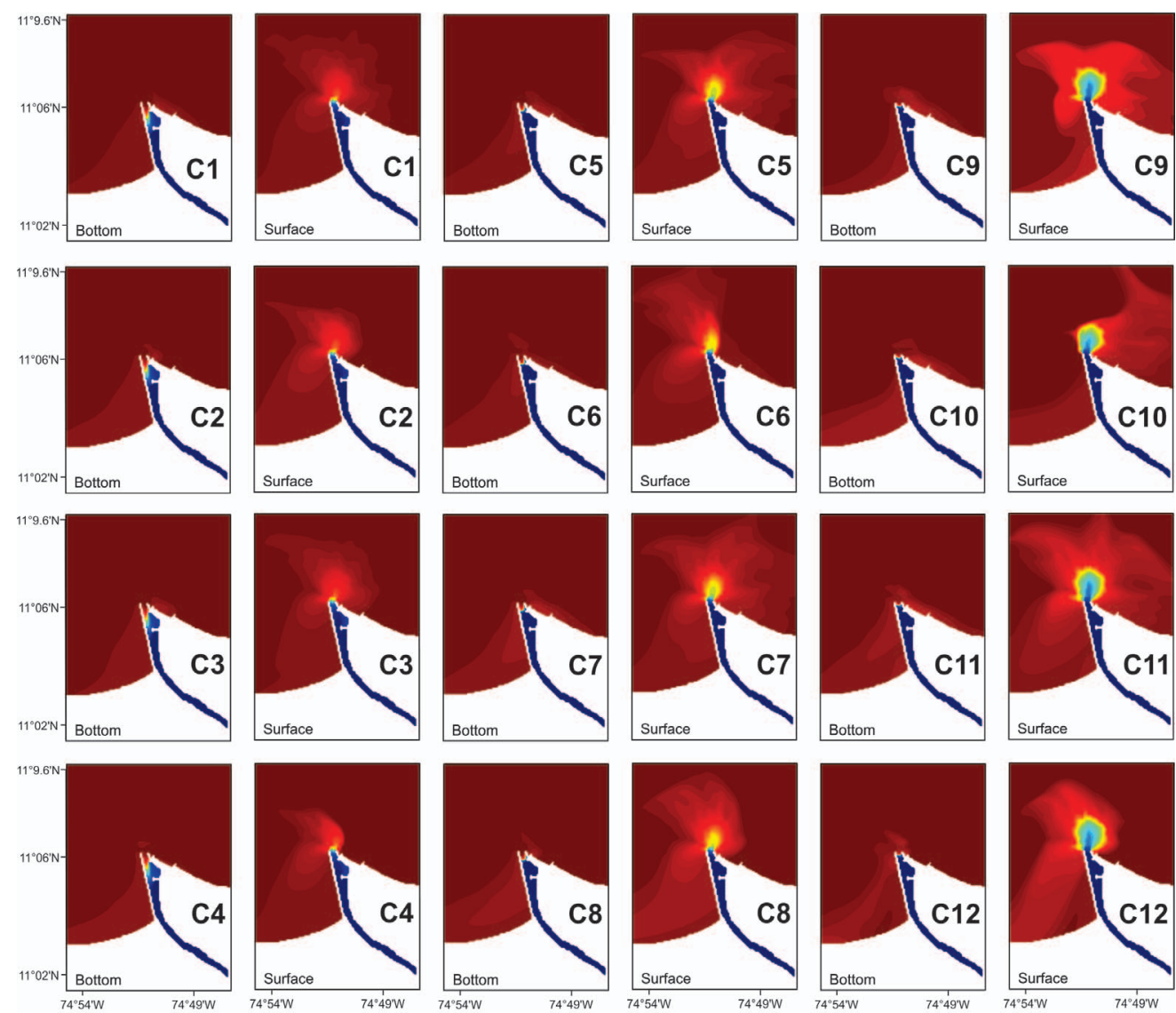

Salinity

$\begin{array}{llllllll}0 & 5 & 10 & 15 & 20 & 25 & 30 & 35\end{array}$

Figure 6. Bottom and superficial distribution of salinity for the different scenarios shown in Table 2 .

proved to significantly influence the distribution of salinity in the offshore surface layers, also altering the maximum extent of the hypopycnal flux defined by the river inputs (Figure 6). Winds coming from the NE drive the migration of the surface riverine plume principally towards the $\mathrm{NW}$ and $\mathrm{SW}$. In contrast, for deeper layers (depth $>10 \mathrm{~m}$ ), the shear stress exerted by the wind did not generate any significant change in the distribution of salinity.

\section{Stratification and Mixing Conditions in the Estuary}

Saltwater intrusion into the navigable channel of the Magdalena River leads to stratification values $\left(n_{\mathrm{s}}\right)$ between 1.0 and $\sim 4.0$. This saltwater intrusion weakens turbulence and creates a moderately stable water column upstream (with $R_{\mathrm{L}}$ values between 2 and 20), as well as a stable water column close to the river mouth (with $R_{\mathrm{L}}>20$ ). At this site, the maximum stability conditions $\left(R_{\mathrm{L}}=\sim 90\right)$ are reached under minimaldischarge conditions (Figure 9). A variation in the stratification and mixing conditions of the water column was observed along the tidal cycle at the control points $\mathrm{p}_{1}, \mathrm{p}_{2}, \mathrm{p}_{3}$, and $\mathrm{p}_{4}$ located 0,1 , 2 , and $4 \mathrm{~km}$ upstream of the river mouth, respectively. For instance, during a tidal cycle under minimal streamflow conditions, tide and wind generated small variations in $n_{\mathrm{s}}$ and $R_{\mathrm{L}}$ without presenting transitions between stratification and mixing conditions. The parameter $n_{\mathrm{s}}$ exhibited larger variations in the control points located upriver, with values around 2.0, while the control point located at the river mouth showed the greater variation of $R_{\mathrm{L}}$, with values between 50 and 130 (Figure 10).

Under maximum-discharge conditions, the discharge tends to preserve the stratification and stability of the water column at the river mouth in spite of any mixing effect from the tide or wind. When discharge decreases, the effect of the tide and wind becomes, however, more relevant, and significant changes in the stratification and mixing conditions of the estuary can be observed (Figure 9). For example, during mean-discharge conditions, when the saltwater convergence front is found close to the mouth of the river, the action of the wind causes an increase in salinity of up to 6 at this saltwater front (Figure 11). On the other hand, during low-discharge conditions, the tide determines the final penetration of the saltwater front, since at high tide and low tide, the front reaches 2.7 and $2.4 \mathrm{~km}$ upstream, respectively. This constitutes a difference of $0.3 \mathrm{~km}$ 

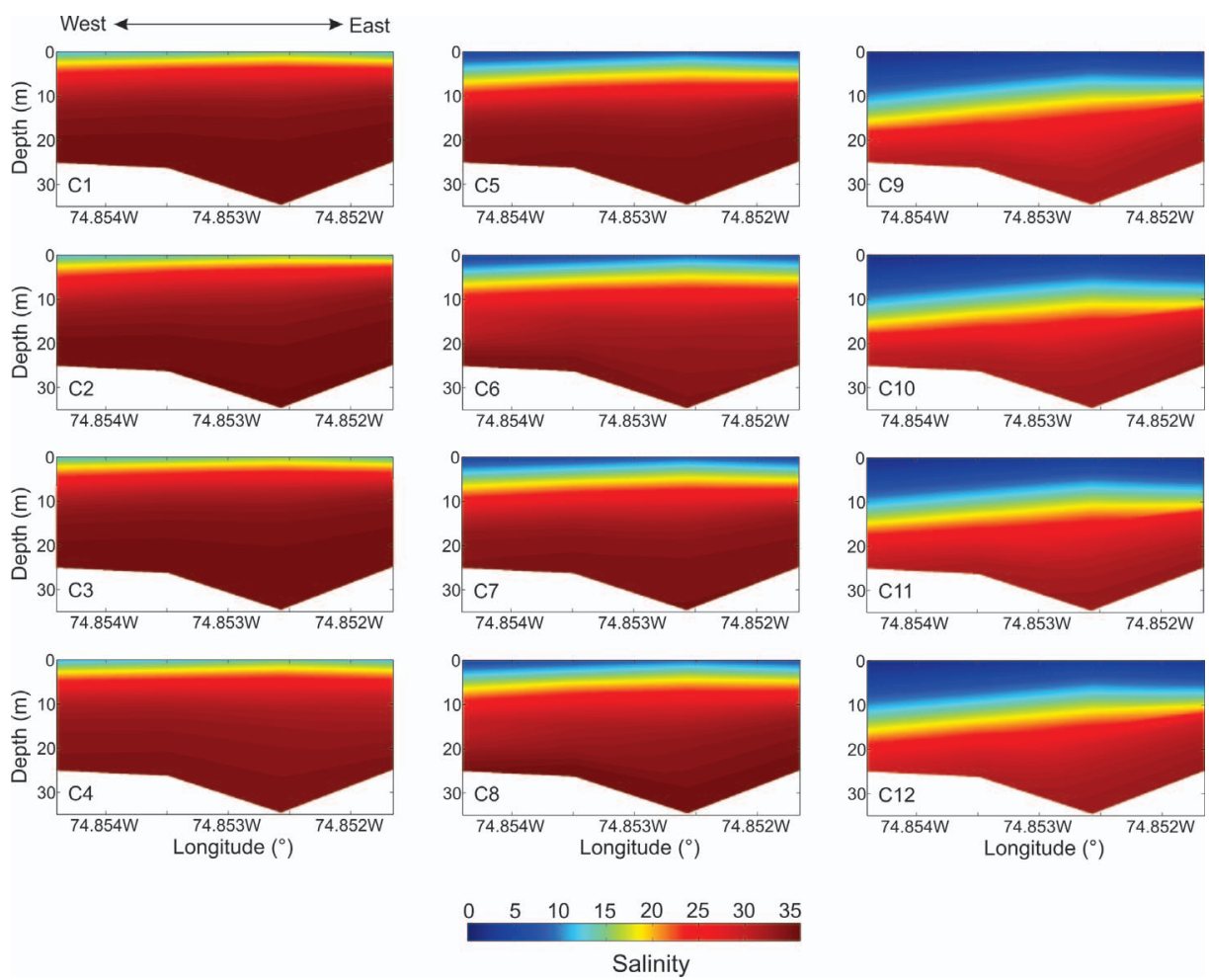

\section{Salinity}

Figure 7. Vertical distribution of salinity along the cross section CD (Figure 1) for the different scenarios shown in Table 2.

in terms of salt-wedge penetration for a tidal range of only $\sim 0.3$ $\mathrm{m}$ (Figure 11).

Under average-discharge conditions, the area of dissolution (i.e. the water domain with a salinity range of $0.5-30$ ) is $\sim 8.8$ $\mathrm{km}^{2}$, with an average depth of $\sim 24 \mathrm{~m}$. As such, the volume of the Magdalena estuary can be estimated as $\sim 0.21 \mathrm{~km}^{3}$. In contrast, under minimum and maximum-discharge conditions, the area of dissolution becomes $\sim 6.16$ and $\sim 19.33 \mathrm{~km}^{2}$, with average depths of $\sim 14$ and $\sim 47 \mathrm{~m}$, respectively. These values correspond to estuary volumes of $\sim 0.086$ and $\sim 0.908 \mathrm{~km}^{3}$,
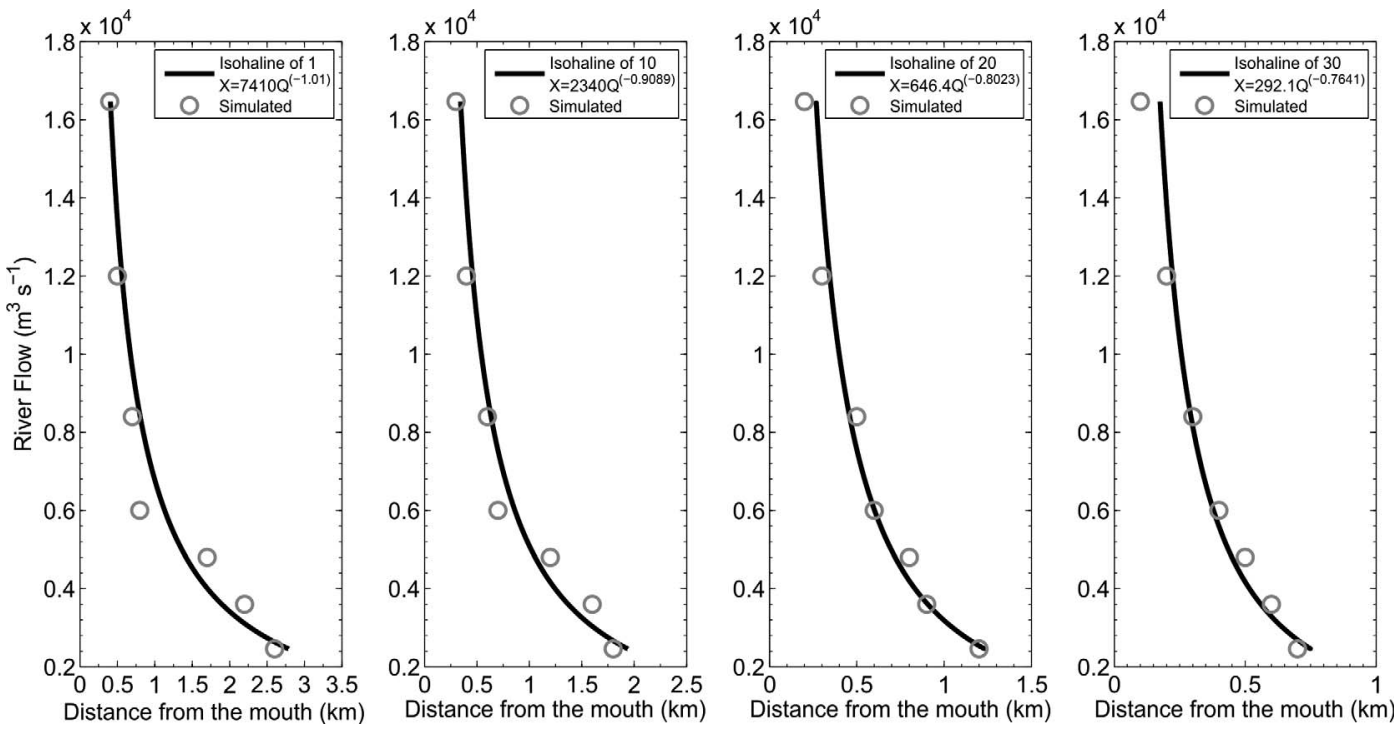

Figure 8. Intrusion of isohalines $(1,10,20$, and 30) upstream of the river mouth as a function of the streamflow. 
Table 4. Functions describing the penetration (X) of the 1, 10, 20 and 30 isolines into the final stretch of the river as a function of the river discharge (Q).

\begin{tabular}{llcr}
\hline \hline Isohaline & Function & $R^{2}$ & $p$ Value \\
\hline 1 & $X=7410 Q^{-1.01}$ & 0.9297 & 0.0014 \\
10 & $X=2340 Q^{-0.9089}$ & 0.9409 & 0.0005 \\
20 & $X=646.4 Q^{-0.8023}$ & 0.9787 & 0.0001 \\
30 & $X=292.1 Q^{-0.7641}$ & 0.9527 & 0.0001 \\
\hline
\end{tabular}

respectively. The estuary volume is relatively low compared to daily freshwater discharge, and the mean depth is relatively high with regard to tidal range. Under these conditions, a highly defined stratified estuary develops, where the interaction between fluvial discharges and tides, even during minimal streamflow and maximum tidal range, is not sufficient to promote efficient mixing through the water column (Figure 12).

\section{DISCUSSION}

Currently, there is limited available information regarding saltwater intrusion at the Magdalena River mouth (e.g., Alvarado, 1992; Alvarez-Silva and Osorio, 2015; Cormagdalena, 2012; Restrepo et al., 2016). Although this information has provided a general approximation to the dynamics of saltwater structure at the mouth, it is insufficient to analyze the effect of the different drivers (i.e. discharge, tide, and wind) and their interaction on the stratification, mixing, and saltwater intrusion. A new approach was performed through the implementation of a 3D hydrodynamic model (MOHID 3D). This model was calibrated and validated using distinct weather scenarios (rainy and dry seasons) and subsequently used to simulate different interactions between the main hydrodynamic drivers (Figure 2E-H). The results showed a marked seasonal change in the stratification state and position of the saltwater/ freshwater interface (Figures 4-12). Decreases in river discharge lead to greater saltwater intrusion into the deeper part of the channel of the river mouth (Figures 4-6). As such, this confirms that the dynamics of saltwater intrusion at the mouth of the Magdalena River depend mostly on the variations in river discharge. This fact was previously suggested by Restrepo et al. (2016) through experimental measurements. The effects of tides and winds on the salt-wedge intrusion are nonnegligible during low and medium river discharges, as shown in Figure 11.

The different simulated scenarios revealed the formation of deep haloclines in the navigable channel and shallow haloclines in the delta front. During high-discharge conditions, the advection flux does not completely displace the convergence front towards the delta, but rather deepens the halocline (Figure 5, C9-C12). On the other hand, under low-discharge conditions, the halocline and thus the stratification conditions, are strengthened (Figure 4, C1-C4). Furthermore, the greater depth at the channel also favors the penetration of the salt wedge into the river, as can be seen in transect CD in Figure 7, where shallower haloclines were found in the deepest part of the cross section due to the effect of the density gradient on the estuarine circulation. This pattern has also been observed in estuaries that experience lateral circulation (e.g., Vigo estuary). These results suggest that increasing the depth of the channel by dredging would favor the penetration of the
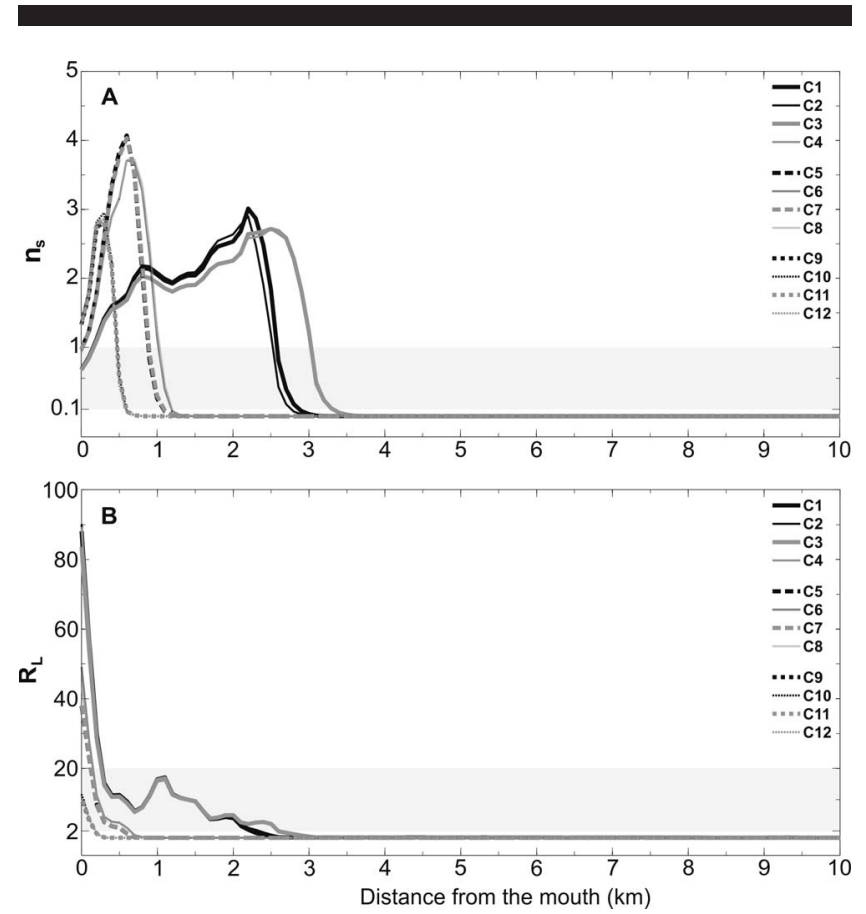

Figure 9. Evolution of the stratification and mixing parameters along the longitudinal profile $\mathrm{AB}$ (from the river mouth to $10 \mathrm{~km}$ upstream) (Figure 1). (A) Stratification parameter $n_{\mathrm{s}}$, where, the band represents the transition zone from a homogeneous to stratified water column. (B) Mixing parameter $R_{\mathrm{L}}$, where, the band represents the transition zone between a steady and unsteady water column.

saltwater convergence front by altering the balances among advection flux, stratification, and shear stress. In fact, it has been reported that the landward migration of the saltwater convergence front after dredging activities has generated significant changes in salt-wedge intrusion and sedimentation patterns (e.g., Wang, Hassan, and Xie, 2006; Wu, Liu, and Wang, 2012). In addition, human intervention at the Magdalena River mouth has been conducted to regulate flow and to reduce siltation rates (Restrepo et al., 2016). These interventions might have modified the salt-wedge dynamics, leading to a lesser landward penetration as a result of river mouth narrowing and the freshwater flux increase (Restrepo et al., 2016).

The length of the salt-wedge intrusion shows a relation with the fluvial discharge $(Q)$ estimated as $Q^{-1 / 3}$ (Monismith et al., 2002; Ralston, Geyer, and Lerczak, 2008). This estimation has been used as a reference for evaluating the response of salt gradients against changes in fluvial discharge (Bowen, 2000; Zahed, Etemad-Shahidi, and Jabbari, 2008). The estimated $Q^{-1 / 3}$ only considers steady shear dispersion as the mechanism triggering upstream salt flux, despite the fact that oscillatory salt flow also plays a major role in highly stratified systems (Chen et al., 2012). The bed morphology and channel geometry significantly affect the length of the salt-wedge intrusion (Ralston, Geyer, and Lerczak, 2008). Therefore, the length of the intrusion might be relatively unresponsive to fluvial discharges, exhibiting deviation from the $Q^{-1 / 3}$ estimate 

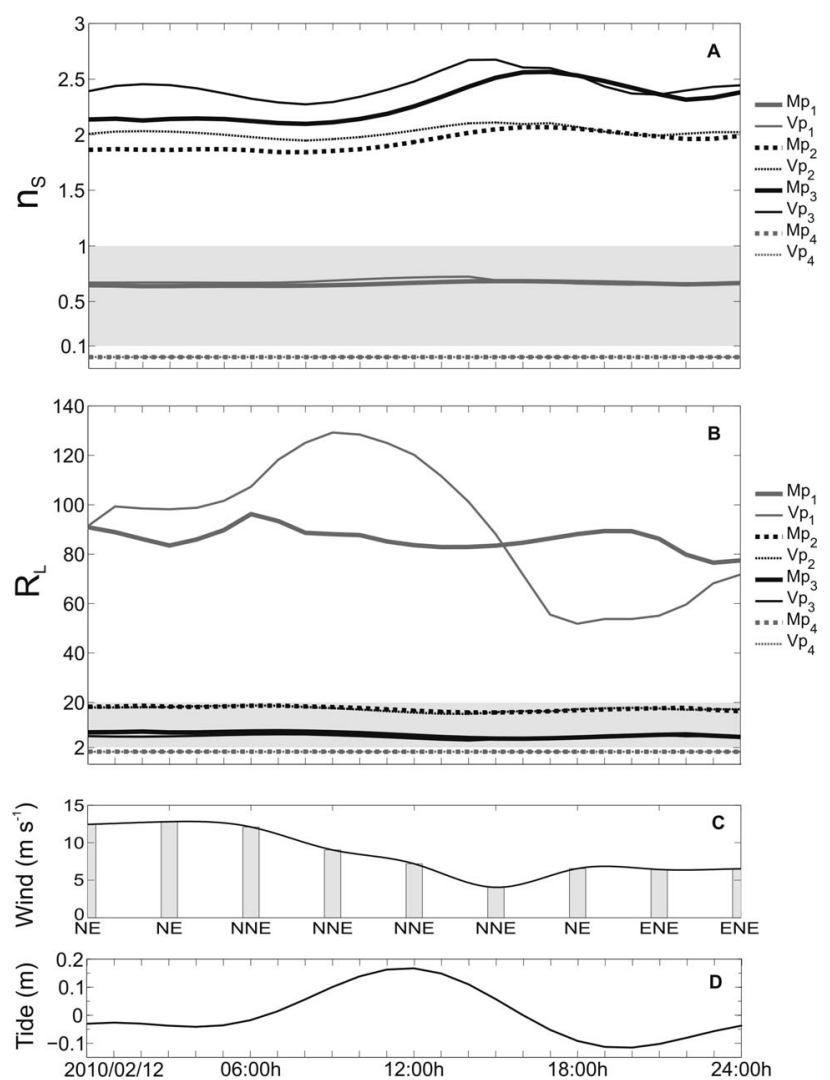

Figure 10. Temporal evolution of the stratification and mixing parameters for the control points shown in Figure 1 during the low-discharge simulation scenarios. (A) Stratification parameter $n_{\mathrm{s}}$, where, the band represents the transition zone from a homogeneous to stratified water column. (B) Mixing parameter $R_{\mathrm{L}}$, where, the band represents the transition zone between a steady and unsteady water column. (C) Magnitude and direction of the wind. (D) Water level. The dotted "V" and continuous "M" lines represent scenarios with and without wind, respectively.

(Aristizabal and Chant, 2013). This deviation was observed at the Magdalena River estuary, where the maximum intrusion of the 1 and 30 isohalines was proportional to $Q^{-1.01}$ and $Q^{-0.76}$, respectively.

Changes in the stratification parameter $\left(n_{\mathrm{s}}\right)$ and the Richardson layered number $\left(R_{\mathrm{L}}\right)$ under different scenarios also reflect the displacement of the interface between the two water masses (saltwater/freshwater): The final stretch of the Magdalena River is characterized by alternation between well-mixed and stratified conditions (Figure 9). The change in the stratification state is determined by the changes in the mixing mechanisms. As explained before, the term $R_{\mathrm{L}}$ is widely accepted for estimating the efficiency of buoyancy in mitigating the instabilities generated inside the water column by turbulence or internal waves (i.e. Holmboe, Kelvin-Helmholtz instability). For large $R_{\mathrm{L}}$ values ( $>20$ ), it is considered that there are no instabilities, either because the shear force is very weak or because buoyancy is predominant. In contrast, for low $R_{\mathrm{L}}$ values $(<2)$, the effect of the shear force is dominant, and any perturbation can cause an instability and generate mixing throughout the water column (Prandle, 2009). The modelling results show that when river discharge decreases (i.e. decrease in $\bar{u}$ ), the $R_{\mathrm{L}}$ value increases (Figure 9 ). Therefore, under lowdischarge conditions (cases $\mathrm{C} 1-\mathrm{C} 4$ ), stratification becomes effective $\sim 2.7 \mathrm{~km}$ upstream of the river mouth as a result of the decrease in river flux and the increase in the density difference between the two masses of water $\left(\rho_{\mathrm{b}}-\rho_{\mathrm{s}}\right)$. This makes the turbulence caused by bottom friction less efficient for mixing the water column, resulting in turn in a well-defined extended stratification, as indicated by the stratification parameter $\left(n_{\mathrm{s}}\right)$ (Figure 9). Other studies have also demonstrated that in stratified flows, the vertical fluctuations in turbulence are weakened or suppressed, with a proportion of the turbulent energy dissipating along the longitudinal component (e.g., Dyer, Christie, and Manning, 2004; Geyer, Hill, and Kineke, 2004; Kitheka, Obiero, and Nthenge, 2005). Therefore, the stratification induced by salt-wedge intrusion during low streamflow conditions leads to a reduction in the vertical mixing and subsequent ETM formation, promoting suspended particulate matter settling (Restrepo et al., 2018).

The type of stratification observed in the simulations is characteristic of estuaries experiencing two-layer circulation and the formation of a salt wedge. This is common at the mouths of large rivers, and it represents the balance between river advection and vertical stratification. The friction between the two water layers is also important, as river water flowing seaward balances the pressure gradient by forcing saltwater outwards and stopping the salt wedge (Prandle, 2009). Considering these results, it can be assumed that the intrusion of the salt wedge is a function of river discharge, as was effectively demonstrated here (Figure 8; Table 4). In the equations shown in Table 4, the tide and wind effects are not taken into account because they are secondary contributors to the shifts in the location of the salt front (Figure 11). The nonlinear relationship between the river discharge and the position of the salt wedge shown in Figure 8 can be explained by the irregular morphology of the river bed, where shallow areas act as an obstacle for the progression of the salt wedge, and by the nonlinearity of frictional processes within the bottom layers and the halocline (e.g., Prandle, 2009).

The position of the convergence front can thus be estimated with a significant level of confidence using these functions for average and low streamflow conditions (Table 4). For example, the simulations show that when the system is subjected to high streamflows $\left(>7500 \mathrm{~m}^{3} \mathrm{~s}^{-1}\right)$, the 30 isohaline only reaches the depression and mouth frontal bar located $0.3 \mathrm{~km}$ upstream of the mouth. This pattern agrees with the longitudinal distribution of salinity measured by Restrepo et al. (2016) during discharges of $\sim 8000 \mathrm{~m}^{3} \mathrm{~s}^{-1}$, in which the 1 isohaline penetrated as far as $0.4 \mathrm{~km}$ upstream of the river mouth. For a discharge of $6000 \mathrm{~m}^{3} \mathrm{~s}^{-1}$, which is a medium streamflow $\left(4500 \mathrm{~m}^{3} \mathrm{~s}^{-1}<Q<\right.$ $7500 \mathrm{~m}^{3} \mathrm{~s}^{-1}$ ), the maximum penetration of an isohaline of 1 into the river is estimated to be $0.8 \mathrm{~km}$ upstream of the river mouth. A similar result was reported by Cormagdalena (2012), in which a saltwater influence was found as far as $0.7 \mathrm{~km}$ from the river mouth with a streamflow of $6200 \mathrm{~m}^{3} \mathrm{~s}^{-1}$. However, for low discharges $\left(<4500 \mathrm{~m}^{3} \mathrm{~s}^{-1}\right)$, the model shows that the salt wedge propagates further upstream, but not as much as measurements by Restrepo et al. (2016) show. While the model predicts 

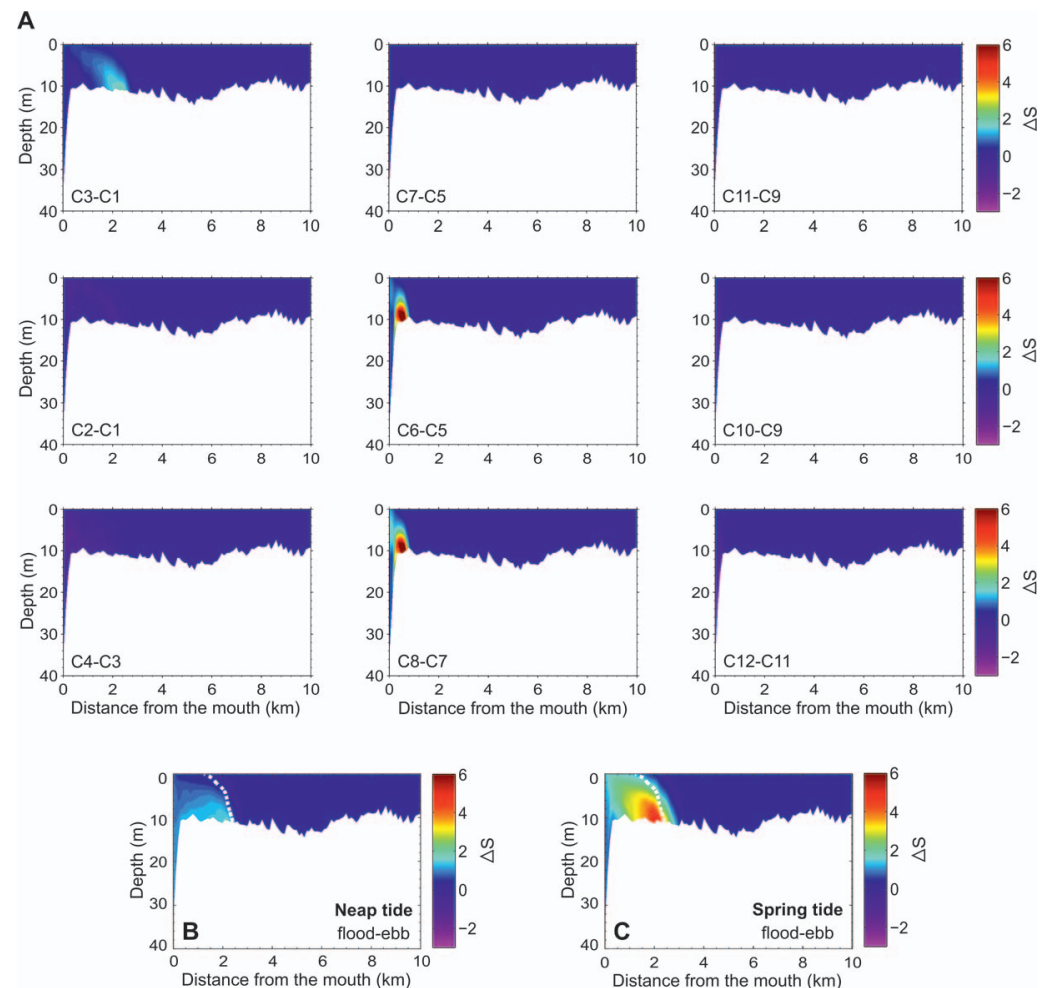

Figure 11. Spatial differences in salinity along the longitudinal profile (AB) as a consequence of (A) variations in the driving mechanisms (tide and wind). The labels identifying each figure represent the difference between the two scenarios (Table 2). For minimum flow condition: (B) variations between flood/ebb states during neap tide, and (C) variations between flood/ebb states during spring tide. The dashed line represents the isohaline of 1 (no tide).

a penetration of $1.4 \mathrm{~km}$ for the isohaline of 1 , the measurements show a penetration of $6.2 \mathrm{~km}$ upstream of the river mouth. For the minimum reported discharge $\left(1520 \mathrm{~m}^{3} \mathrm{~s}^{-1}\right)$, the model estimates the salt wedge (e.g., isohaline of 1 ) to penetrate as far as $4.5 \mathrm{~km}$ upstream of the mouth. The differences in salt-wedge penetration between the results of this study and those reported by Restrepo et al. (2016) could be due to the effects

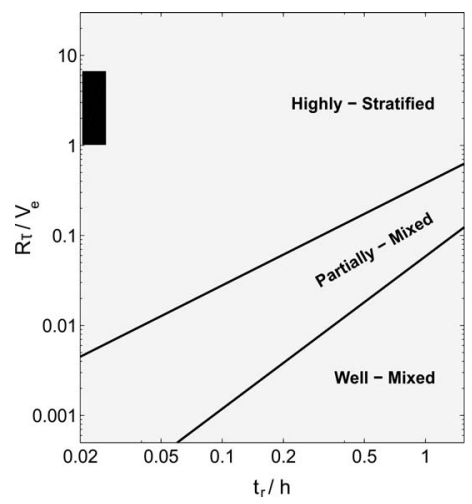

Figure 12. Vijith and Shetye (2012) stratification diagram for the estuary of the Magdalena River, where, $t_{\mathrm{r}}$ : tidal range $(\mathrm{m}), R$ : discharge $\left(\mathrm{m}^{3} \mathrm{~s}^{-1}\right), h$ : average depth $(\mathrm{m}), \tau$ : timescale (1 day), and $V_{\mathrm{e}}$ : volume of the estuary $\left(\mathrm{m}^{3}\right)$. of morphology on the landward propagation of the salt wedge. Discrepancies in the length of the salt-wedge penetration might be linked to differences in the bathymetry considered in the current numerical simulation and that existing during previous measurements (Restrepo et al., 2016). Such differences are very likely, considering that significant changes of the bed morphology occur as a result of the periodic dredging performed in the Magdalena River mouth. Moreover, some bathymetric features may not be fully reproduced by the 3D hydrodynamic model because of the relationships among spatial discretization (horizontal/vertical), time lapse, and the stability of the numerical model. Accurate bathymetry improves the simulation of salt-wedge penetration, highlighting the effect of bed morphology on such process (Ibañez, Pont, and Prat, 1997). A study by Alvarado (1992) reported salt-wedge propagation of $\sim 22 \mathrm{~km}$ upstream of the mouth during a discharge of $2100 \mathrm{~m}^{3} \mathrm{~s}^{-1}$. Nonetheless, this estimation seems to be unlikely because a saltwater prism of this volume $(\sim 52.8 \times$ $10^{6} \mathrm{~m}^{3}$ ) would require about 20 hours to form considering the geometry of the channel, the thickness of the salt wedge $(<4$ $\mathrm{m})$, and the typical velocity of this density flow $\left(\sim 0.3 \mathrm{~m} \mathrm{~s}^{-1}\right)$, and ignoring diffusive processes. This amount of time clearly exceeds the duration of the tidal cycle that occurs at the mouth of the Magdalena River.

As previously mentioned, even though the estuary of the Magdalena River is subjected to a microtidal environment with a maximum tidal range of $0.4 \mathrm{~m}$, the tide still has an influence 
on the position and structure of the saltwater wedge under minimum-discharge conditions. This enables both an increase in the thickness and a progression of the saltwater front during tidal floods (Figure 11). Under medium-discharge conditions, the force of the wind prevails over the force of the tide, favoring the penetration of water with higher salinity (Figure 11). However, a more detailed analysis of wind effects on the distribution of salinity, mixing conditions, and the stratification state of the water column shall be carried out by evaluating scenarios using different magnitudes and directions of winds, under different tidal and discharge situations.

The stratification and formation of a surface plume (i.e. hypopycnal flow) on a delta front are typical processes of rivers that discharge into deep basins, close to submarine canyons, and that experience weak tides (e.g., Congo, Sepik, Fraser). In these cases, the frontal mixing zone is extremely abrupt, with only a few hundred meters between the river domain and the ocean domain (Geyer, Hill, and Kineke, 2004). The position and extent of the fontal zone depend on the bathymetry, tidal conditions, and wave energy in the receiving basin. At the Magdalena River, this front appears to extend less than $1.5 \mathrm{~km}$ from the mouth (Figures 4 and 5). Considering that the Magdalena River delta experiences highly energetic waves (Ortíz et al., 2013), the delta front could be considered as partially or well mixed, since the turbulence produced by waves breaking in shallow areas generates mixing throughout the entire water column. Additional studies shall be conducted in order to analyze the effect of waves on mixing conditions and estuarine dynamics. Generally, this results in an increase in turbulence, and consequently a decrease in the vertical salinity gradient (Movellán, 2003).

\section{CONCLUSIONS}

A 3D numerical model was calibrated and validated in the Magdalena River estuary under different physical conditions, yielding relatively high and low Skill and RMSE values, respectively. The simulation of different scenarios of streamflow, tide, and wind patterns revealed significant seasonal changes in vertical distribution of salinity and mixing conditions. The salt wedge penetrates upstream under minimal- and medium-discharge conditions. In contrast, under maximum-discharge conditions, the saltwater convergence front remains confined to the river mouth. These results demonstrate that the dynamics of the salt wedge in the Magdalena River are mainly controlled by the river's discharge. Saltwater intrusion into the navigable channel of the Magdalena River leads to stratification, which in turn leads to changes in the mixing conditions. Under maximum-discharge conditions, the flow of the river tends to preserve the stratification and stability of the water column at the river mouth in spite of any mixing effect from the tide or wind. When discharge decreases, however, the effects of the tide and wind become more relevant, and significant changes in the stratification and mixing conditions of the estuary can be observed. Despite microtidal conditions, the tide still has an influence on the position and structure of the saltwater wedge under minimum-discharge conditions. This enables both an increase in the thickness and a progression of the saltwater front during tidal floods. Under medium-discharge conditions, the force of the wind prevails over the force of the tide, favoring the penetration of water with higher salinity.

Under low-discharge conditions, stratification becomes effective at $\sim 2.7 \mathrm{~km}$ upstream of the river mouth as a result of the decrease in river flux and the increase in the density difference between the two masses of water. This makes the turbulence caused by bottom friction less efficient for mixing the water column, resulting in turn in a well-defined extended stratification, as indicated by the stratification parameter $\left(n_{\mathrm{s}}\right)$. The final stretch of the Magdalena River is characterized by alternation between well-mixed and stratified conditions. The halocline and thus the stratification conditions are strengthened under low-discharge conditions. Furthermore, the greater depth of the channel also favors the penetration of the salt wedge into the river, where shallower haloclines were found in the deepest part of the cross section due to the effect of the density gradient on the estuarine circulation. These results suggest that increasing the depth of the channel by dredging would favor the penetration of the saltwater convergence front by altering the balance among advection flux, stratification, and shear stress.

During high-discharge conditions, the advection flux does not completely displace the convergence front towards the delta, but rather it deepens the halocline. In addition, surface salinity at the delta front was notably reduced, leading to a large area of dissolution. The surface layer of the delta front exhibited salinities of 10,20 , and 30 up to $1.0,2.4$, and $3.8 \mathrm{~km}$ offshore from the river mouth, respectively. The wind dynamics also proved to significantly influence the distribution of salinity in the offshore surface layers and alter the maximum extent of the hypopycnal flux defined by the river inputs. Under averagedischarge conditions, the area of dissolution is $\sim 8.8 \mathrm{~km}^{2}$, with an average depth of $\sim 24 \mathrm{~m}$. As such, the volume of the Magdalena estuary can be estimated as $\sim 0.21 \mathrm{~km}^{3}$. Alternatively, under minimum- and maximum-discharge conditions, the area of dissolution becomes $\sim 6.16$ and $\sim 19.33 \mathrm{~km}^{2}$, respectively, with average depths of $\sim 14$ and $\sim 47 \mathrm{~m}$, respectively. These values correspond to estuary volumes of $\sim 0.086$ and $\sim 0.908 \mathrm{~km}^{3}$, respectively.

\section{ACKNOWLEDGMENTS}

This research was partially funded by grants from the Inter-American Institute for Global Change Research (IAI) CRN3038, which is supported by the U.S. National Science Foundation (Grant GEO-1128040), and from Colciencias (Proyecto 121571250890 Convocatoria 745: "Hacia el entendimiento de la turbulencia y la floculación en desembocaduras tropicales-Procesos fundamentales en la formación de zonas de máxima turbidez y el transporte de sedimentos").

\section{LITERATURE CITED}

Abbott, M.; Damsgaard, A., and Rodenhuis, G., 1973. System 21, Jupiter, a design system for two-dimensional nearly-horizontal flows. Journal of Hydraulic Research, 11(1), 1-28.

Alvarado, M., 1992. Río Magdalena (Sector Calamar-Bocas de Ceniza): Caracterización Hidrosedimentológica y Cuña Salina Basada en Mediciones Realizadas durante 20 Campañas. Barranquilla, Colombia: Ministerio de Obras Públicas y Transporte, Technical Report, 43p. 
Alvarez-Silva, O. and Osorio, A., 2015. Salinity gradient energy potential in Colombia considering site specific constraints. Renewable Energy, 74, 737-748.

Andrade, C., 1993. Análisis de la velocidad del viento en el mar Caribe. Boletín Científico Centro de Investigaciones Oceanográficas e Hidrográficas, 13, 33-43.

Arakawa, A., 1966. Computational design for long-term numerical integration of the equations of fluid motion: Two-dimensional incompressible flow. Part I. Journal of Computational Physics, 1(1), 119-143.

Aristizabal, M. and Chant, R., 2013. A numerical study of salt fluxes in Delaware Bay estuary. Journal of Physical Oceanography, 43(8), 1572-1588.

Bernal, G.; Ruiz-Ochoa, M., and Beier, E., 2010. Variación estacional e interanual de los campos de temperatura superficial de la cuenca Colombia, mar Caribe. Santa Marta, Colombia: INVEMAR, Publicaciones Especiales de INVEMAR 21, 578p.

Bowen, M.M., 2000. Mechanisms and Variability of Salt Transport in Partially Stratified Estuaries. Cambridge, Massachusetts: Massachusetts Institute of Technology, Ph.D. thesis, 171p.

Burchard, H. and Baumert, H., 1998. The formation of estuarine turbidity maxima due to density effects in the salt wedge: A hydrodynamic process study. Journal of Physical Oceanography, 28(2), 309-321.

Canuto, V.; Howard, A.; Cheng, Y., and Dubovikov, M., 2001. Ocean turbulence. Part I: One point closure model-Momentum and heat vertical diffusivities. Journal of Physical Oceanography, 31(6), $1413-1426$.

Chen, S.N.; Geyer, W.R.; Ralston, D.K., and Lerczak, J.A., 2012. Estuarine exchange flow quantified with isohaline coordinates: Contrasting long and short estuaries. Journal of Physical Oceanography, 42(5), 748-763.

Coelho, H.S.; Neves, R.R.; Leitão, P.C.; Martins, H., and Santos, A.P., 1999. The slope current along the western European margin: A numerical investigation. Boletín Instituto Español de Oceanografía, 15(1-4), 61-72.

Cormagdalena, 2012. Condiciones Generales del Puerto de Barranquilla, durante Febrero de 2012. Barranquilla, Colombia: Cormagdalena, Technical Report E-004-109-12, 15p.

D'Adamo, N. and Lukatelich, R., 1985. Water Quality of the Murray River Estuary: Summary Report Waterways Commission. Perth, Western Australia: Centre for Water Research, The University of Western Australia, Report 6, 17p.

Delandmeter, P.; Lewis, S.; Lambrechts, J.; Deleersnijder, E.; Legat, V., and Wolanski, E., 2015. The transport and fate of riverine fine sediment exported to a semi-open system. Estuarine, Coastal and Shelf Science, 167, 336-346.

Días, J. and Lopes, J., 2006. Implementation and assessment of hydrodynamic, salt and heat transport models: The case of Ria de Aveiro Lagoon (Portugal). Environmental Modelling \& Software, 21(1), 1-15.

Díaz, J.; Sousa, M.; Bertin, X.; Fortunato, A., and Oliveira, A., 2009. Numerical modeling of the impact of the Ancao Inlet relocation (Ria Formosa, Portugal). Environmental Modelling \& Software, 24(6), $711-725$.

Dyer, K., 1997. Estuaries: A Physical Introduction. New York: John Wiley, 195p.

Dyer, K.; Christie, M., and Manning, A., 2004. The effects of suspended sediment on turbulence within an estuarine turbidity maximum. Estuarine, Coastal and Shelf Science, 59(2), 237-248.

Ercilla, G.; Alonso, B.; Estrada, F.; Chiocci, F.; Baraza, J., and Ferran, M., 2002. The Magdalena turbidite system (Caribbean Sea): Present-day morphology and architecture model. Marine Geology, 185(3-4), 303-318.

Geyer, W.; Hill, P., and Kineke, G., 2004. The transport, transformation and dispersal of sediment by buoyant coastal flows. Continental Shelf Research, 24(7-8), 927-949.

Haralambidou, K.; Sylaios, G., and Tsihrintzis, V., 2010. Salt-wedge propagation in a Mediterranean micro-tidal river mouth. Estuarine, Coastal and Shelf Science, 90(4), 174-184.

Haralambidou, K.; Tsihrintzis, V., and Sylaios, G., 2003. Control of saline wedge intrusion in the estuary of Strymonas river using an air curtain. 8th International Conference on Environmental Science and Technology (Lemnos Island, Greece), pp. 302-309.

Higgins, A.; Restrepo, J.C.; Ortíz, J.C.; Pierini, J., and Otero, L., 2016. Suspended sediment transport in the Magdalena River (Colombia, South America): Hydrologic regime, rating parameters and effective discharge variability. International Journal of Sediment Research, 31(1), 25-35.

Hinwood, J.B., 1994. Short salt wedges and the limit of no salt wedge. In: Pattiaratchi, C. (ed.), Mixing in Estuaries and Coastal Seas. Washington, D.C.: American Geophysical Union, Coastal and Estuarine Studies 50, pp. 267-277.

Ibañez, C.; Pont, D., and Prat, N., 1997. Characterization of the Ebre and Rhone estuaries: A basis for defining and classifying saltwedge estuaries. Limnology and Oceanography, 42(1), 89-101.

Kinne, O.M., 1971. Salinity: Animals-Invertebrates. In: Kinne, O.M. (ed.), Marine Ecology: A Comprehensive, Integrated Treatise on Life in Oceans and Coastal Waters, Volume 1. London: Wiley-Interscience, pp. 821-995.

Kitheka, J.; Obiero, M., and Nthenge, P., 2005. River discharge, sediment transport and exchange in the Tana estuary, Kenya. Estuarine, Coastal and Shelf Science, 63(3), 455-468.

Leendertse, J.J., 1967. Aspects of a Computational Model for LongPeriod Water-Wave Propagation. Santa Monica, California: RAND Corporation, Memorandum RM 5294-PR, 165p.

Luyten, P.J.; Deleersnijder, E.; Ozer, J., and Ruddick, K.G., 1996. Presentation of a family of turbulence closure models for stratified shallow water flows and preliminary application to the Rhine outflow region. Continental Shelf Research, 16(1), 101-130.

Manning, A.J.; Baugh, J.V.; Spearman, J.R., and Whitehouse, R.J.S., 2010. Flocculation settling characteristics of mud:sand mixtures. Ocean Dynamics, 60(2), 237-253.

Martins, F.; Neves, R., and Leitão, P., 1998. A three-dimensional hydrodynamic model with generic vertical coordinate. In: Babovic, V. and Larsen, L.C. (eds.), Hydroinformatics 98. Rotterdam, The Netherlands, Balkema, pp. 1403-1410.

Martins, F.; Neves, R.; Leitão, P., and Silva, A., 2001. 3D modeling in the Sado estuary using a new generic vertical discretization approach. Oceanologica Acta, 24, S1-S12.

Martins, I.; Días, J.; Fernandes, E., and Muelbert, J., 2007. Numerical modelling of fish eggs dispersion at the Patos Lagoon estuary, Brazil. Journal of Marine Systems, 68(3-4), 537-555.

Mateus, M.; Riflet, G.; Chambel, P.; Fernandes, L.; Fernandes, R. Juliano, M.; Campuzano, F.; Pablo, H.D., and Neves, R., 2012. An operational model for the West Iberian coast: Products and services. Ocean Science, 8(4), 713-732.

Monismith, S.G.; Kimmerer, W.; Burau, J.R., and Stecey, M.T., 2002. Structure and flow-induced variability of subtidal salinity field in northern San Francisco Bay. Journal of Physical Oceanography, 32(11), 3003-3019.

Movellán, E., 2003. Modelado de la Cuña Salina y del Flujo de Nutrientes en el Tramo Estuarino del Río Ebro. Barcelona, Spain: Universidad de Barcelona, Ph.D. dissertation, 232p.

NEDECO (Netherlands Engineering Consultants), 1973. Rio Magdalena and Canal del Dique survey project. The Hague, The Netherlands: NEDECO, Technical Report, 397p.

Officer, C.B., 1976. Physical Oceanography of Estuaries. New York: Wiley, 465p.

Oliveira, A.; Fortunato, A., and Pinto, L., 2006. Modelling the hydrodynamics and the fate of passive organisms in the Guadiana estuary. Estuarine, Coastal and Shelf Science, 70(1-2), 76-84.

Ortíz, J.; Otero, L.; Restrepo, J.C.; Ruiz, J., and Cadena, M., 2013. Cold fronts in the Colombian Caribbean and their relationship to extreme wave events. Natural Hazards and Earth System Sciences, 13(11), 2797-2804.

Prandle, D., 2009. Estuaries: Dynamics, Mixing, Sedimentation and Morphology. Cambridge: Cambridge University Press, 236p.

Ralston, D.K.; Geyer, W.R., and Lerczak, J.A., 2008. Subtidal salinity and velocity in the Hudson River estuary: Observations and modeling. Journal of Physical Oceanography, 38(4), 753-770.

Rattray, M. and Mitsuda, E., 1974. Theoretical analysis of conditions in a salt wedge. Estuarine and Coastal Marine Science, 2(4), 375394. 
Restrepo, J.C.; Escobar, J.; Otero, L.; Franco, D.; Pierini, J., and Correa, I., 2017. Factors influencing the distribution and characteristics of surface sediment in the Bay of Cartagena, Colombia. Journal of Coastal Research, 33(1), 135-148.

Restrepo, J.D. and Kjerfve, B., 2000. Magdalena River: Interannual variability (1975-1995) and revised water discharge and sediment load estimates. Journal of Hydrology, 235(1-2), 137-149.

Restrepo, J.C.; Ortíz, J.C.; Pierini, J.; Schrottke, K.; Maza, M.; Otero, L., and Aguirre, J., 2014. Freshwater discharge into the Caribbean Sea from the rivers of northwestern South America (Colombia): Magnitude, variability and recent changes. Journal of Hydrology, 509, 266-281.

Restrepo, J.C.; Schrottke, K.; Traini, C.; Bartholoma, A.; Ortíz, J.C.; Otero, L.; Ospino, S., and Orejarena, A., 2018. Estuarine and sediment dynamics in a microtidal tropical delta of high fluvial discharge: Magdalena River delta (Colombia, South America). Marine Geology, 398, 86-98.

Restrepo, J.C.; Schrottke, K.; Traini, C.; Ortíz, J.C.; Orejarena, A.; Otero, L.; Higgins, A., and Marriaga, L. 2016. Sediment transport regime and geomorphological change in a high discharge tropical delta (Magdalena River, Colombia): Insights from a period of intense change and human intervention (1990-2010). Journal of Coastal Research, 32(3), 575-589.

Rodi, W., 1987. Examples of calculation methods for flow and mixing in stratified fluids. Journal of Geophysical Research, 92(C5), 53055328.

Ruiz-Ochoa, M.; Bernal, G.; Beier, E., and Osorio, A., 2010. La Salinidad en la Cuenca Colombia, Mar Caribe. Santa Marta, Colombia: INVEMAR, Publicaciones Especiales de INVEMAR 21, $578 \mathrm{p}$.
Simpson, J.E., 1987. Gravity Currents in the Environment and Laboratory. Chichester, U.K.: Ellis Horwood Limited, 244p.

Smagorinsky, J., 1963. General circulation experiments with the primitive equations. Monthly Weather Review, 91(3), 99-164.

Syvitski, J. and Saito, Y., 2007. Morphodynamics of deltas under the influence of humans. Global and Planetary Change, 57(3-4), 261282.

UNESCO (United Nations Educational, Scientific and Cultural Organization), 1981. Tenth Report of the Joint Panel on Oceanographic Tables and Standards. Sidney, Canada: UNESCO, Technical Papers in Marine Science, 25p.

Van Rijn, L.C., 2005. Estuarine and coastal sedimentation problems. International Journal of Sediment Research, 20, 39-51.

Vaz, N.; Dias, J.M., and Leitão, P.C., 2009. Three-dimensional modelling of a tidal channel: The Espinheiro Channel (Portugal). Continental Shelf Research, 29(1), 29-41.

Vijith, V. and Shetye, S.R., 2012. A stratification prediction diagram from characteristics of geometry, tides and runoff for estuaries with a prominent channel. Estuarine, Coastal and Shelf Science, 98, 101-107.

Wang, S.; Hassan, M., and Xie, X., 2006. Relationship between suspended sediment load, channel geometry and land area increment in the Yellow River delta. Catena, 65(3), 302-314.

Wu, J.; Liu, J., and Wang, X., 2012. Sediment trapping of turbidity maxima in the Changiiang Estuary. Marine Geology, 303-306, 1425.

Zahed, F.; Etemad-Shahidi, A., and Jabbari, E., 2008. Modeling of salinity intrusion under different hydrological conditions in the Arvand River Estuary. Canadian Journal of Civil Engineering, 35(12), 1476-1480.

\section{$\square$ SUMMARY OR EXTENDED ABSTRACT IN NATIVE LANGUAGE $\square$}

La desembocadura del Río Magdalena (Bocas de Ceniza) en el Mar Caribe forma un estuario micro-mareal que ha sido objeto de numerosas intervencione destinadas a garantizar la navegabilidad hacia el puerto de Barranquilla. No obstante, a pesar de estas intervenciones, aún son frecuentes los procesos significativos de sedimentación en esta zona. Entender la dinámica de la intrusión salina y las condiciones de mezcla es un pre-requisito fundamental para analizar la dinámica sedimentaria en este tipo de estuarios. Se evaluaron los efectos de la descarga fluvial, la marea y el viento sobre la estratificación, las condiciones de mezcla y la dinámica de la intrusión salina en el estuario del Río Magdalena. Se implementó el modelo hidrodinámico tridimensional MOHID la calibración y validación del modelo se realizaron utilizando datos de temperatura y salinidad recolectados de campañas hidrográficas. El modelo presenta una habilidad predictiva (Skill) mayor a 0.90 . Con el fin de cubrir un rango amplio de variabilidad en los forzadores (descarga fluvial, marea y viento), se simularon las condiciones registradas en 2010 donde se presentaron ambas fases del evento ENOS (El Niño-Oscilación del Sur). Durante este año la descarga fluvial osciló entre 2465 y $16463 \mathrm{~m}^{3} \mathrm{~s}^{-1}$. Los resultados revelan una estratificación, estuario de cuña salina, cuya dinámica está dominada principalmente por la descarga fluvial. La marea y los vientos pueden alterar la intrusión salina principalmente durante los periodos de baja descarga fluvial. 